\title{
Overvaluation and earnings management: Does the degree of overvaluation matters? *
}

\section{Chau Duong a , Gioia Pescetto ${ }^{\text {b }}$}

Abstract: We examine whether the choice of earnings management strategies employed by managers of overvalued firms depends on the degree of market overvaluation. By distinguishing between substantially overvalued and relatively overvalued firms, we find that substantially overvalued firms significantly inflate earnings using both accruals-based and real earnings management. In contrast, managers of relatively overvalued firms do not engage in accruals-based earnings management and their firms' accounts tend to report higher discretionary expenses. The reported higher discretionary expenses of relatively overvalued firms are comparable to the discretionary expenses of firms in the expanding stage of their business life cycle, a pattern consistent with relatively overvalued firms increasing discretionary expenses to finance growth and hence justify the high market valuation. Overall, we show that the existing evidence on income-increasing earnings management by overvalued firms is mainly driven by the pressure to sustain the high market valuation of firms that are substantially overvalued.

\section{JEL classification: G14, M41}

Keywords: Earnings management, real earnings management, accruals-based earnings management, overvalued equity, market mispricing.

\footnotetext{
${ }^{a}$ Royal Docks School of Business and Law, University of East London, Stratford Campus, Water Lane, London, E15 4LZ. Corresponding author. Telephone: 0208 2236036. Email: c.duong@uel.ac.uk.

${ }^{\mathrm{b}}$ Portsmouth Business School, University of Portsmouth, Richmond Building, Portland Street, Portsmouth, PO1 3DE. Telephone: 0239 2844057. Email: gioia.pescetto@ port.ac.uk

* The paper has greatly benefited from useful discussions and comments from Steven Young, William Rees, Andrew Stark, Brian Singleton-Green, Alan Goodacre, Martin Walker, Mark Hughes, Gordon Alexander, Lawrence Kryzanowski, Philip Gharghori, J. Henk Von Eije, Lorne Switzer, Marta GomezPuig, Christian Riis Flor, Alexander Subbotin, Victoria Krivogorsky, Edmund Keung, Benedikt Link, Roger Silvers, Jia Liu, Shen Yun, Tuan Ho. We would also like to thank the editors of the Accounting and Business Research and two anonymous reviewers for valuable suggestions and comments. All remaining errors are ours.
} 


\section{Introduction}

In this paper, we empirically examine whether and how managers engage in various strategies of earnings management in response to different degrees of market overvaluation. This investigation is motivated by the agency cost theory of overvalued equity proposed by Jensen (2005), which predicts that managers of overvalued firms exercise income-increasing earnings management opportunistically to maintain the overvaluation of their firms. Jensen's opportunistic hypothesis is supported by evidence showing that overvalued firms significantly inflate earnings through both accruals-based earnings management (AEM hereafter) and real earnings management (REM hereafter) (Chi and Gupta, 2009; Houmes and Skantz, 2010; Badertscher, 2011).

Jensen (2005) emphasizes that the motive for earnings management is only applicable to substantially overvalued firms. However, most of the existing literature testing Jensen's hypothesis does not directly test the behaviour of substantially overvalued firms. Instead, the extant empirical literature focuses on a group of firms whose market valuation is higher than the rest of the sample, which is likely to comprise some substantially overvalued (SOV hereafter) firms together with many relatively overvalued (ROV hereafter) firms. The managers of both SOV and ROV firms have incentives to sustain the overvaluation because the wealth of the managers is typically tied to stock prices, for example, through performance-based bonuses or stock options. However, the behaviour of managers of SOV and ROV firms is likely to differ since the strength of their incentives depends on the degree of the firm's overvaluation. Jensen (2005) explains that managers of SOV firms have no option but to manage earnings since they could not deliver the performance expected by the market. The only alternative to managing earnings would be to disclose the overvaluation and allow the market to correct the mispricing, but as Jensen (2005, p.10) argues, "there has simply been no listening in boards for this problem".

In contrast, ROV firms might have other options than managing earnings. If the market overvaluation is modest, managers may believe that they will be able to deliver the performance 
expected by the market and, thus, have no need to manage earnings. It is also likely that managers of ROV firms could take advantage of market sentiments to further increase the stock price of their firms. Polk and Sapienza (2009) explain that overvaluation might incentivise firms to increase investment since the increased investment 'caters' to the sentiment of the market, delivers a prospect of greater growth and justifies the high market price. Increasing investment can lead to a better long-term outcome for shareholders than managing earnings and thus supports the high stock price. However, increasing investment is not a viable option for managers of SOV firms because increasing investment would reduce short-term earnings. This reduction in earnings would further increase the already wide gap between reported and expected performance and cause a downward pressure on share prices.

Therefore, we infer that the existing evidence of income-increasing earnings management is mainly driven by the behaviour of SOV firms and argue that distinguishing between SOV and ROV firms would generate more insights into the issue of whether and how managers of overvalued firms manage earnings. Thus, we hypothesize that only managers of SOV firms inflate earnings, while managers of ROV firms refrain from managing earnings and follow other strategies to sustain overvaluation.

Using a sample of UK listed firms over the period from 1995 to 2012, we investigate whether managers of SOV and ROV firms engaged in AEM and REM. We estimate discretionary accruals using the modified Jones (1991) model to proxy for AEM and abnormal discretionary expenses following Roychowdhury (2006) to proxy for REM. We follow Rhodes-Kropf et al. (2005) to estimate the firm's intrinsic value and use the price-to-value ratio as a proxy for the degree of mispricing. In each industryyear, we sort firms by the price-to-value ratio. We then define SOV firms as those with the price-tovalue ratio higher than or equal to the corresponding $95^{\text {th }}$ percentile and ROV firms as those with the price-to-value ratio higher than or equal to the $80^{\text {th }}$ percentile but smaller than the $95^{\text {th }}$ percentile. Although the cut-off point separating SOV form ROV firms is unavoidably arbitrary, it is reasonable to 
differentiate the two groups in terms of the degree of overvaluation, with SOV firms having a significantly higher price-to-value ratio than ROV firms ${ }^{1}$.

The main findings present evidence consistent with managers of SOV firms inflating earnings, using both AEM and REM, in the year after the substantial overvaluation is identified. In contrast, ROV firms are found to have higher discretionary expenses than SOV firms and they do not engage in AEM. We argue that, rather than an attempt to manage earnings, the higher discretionary expenses exhibited by ROV firms are consistent with firms increasing discretionary expenses (e.g., research and development, and advertising) to deliver growth and hence satisfy the high market expectations. To shed further light on our documented evidence of higher discretionary expenses of ROV firms, we also examine the pattern of abnormal discretionary expenses of SOV and ROV firms at different stages of the business life cycle. Firms in the expanding phase typically have more growth opportunities and their operating efficiency is not yet maximized (Dickinson, 2011). Hence, being in the expanding phase often leads firms to make higher investments in discretionary operating and capital expenditure. Although higher discretionary expenses result in lower reported earnings, the market usually interprets higher expenditure as good news for firms in the expanding phase, as suggested by Polk and Sapienza (2009). Mature and stagnant firms, on the contrary, are generally not involved in activities that lead to high discretionary expenses, as the market would usually react negatively to such behaviour. Hence, if a mature or stagnant firm increases discretionary expenses, it would normally affect stock price negatively.

Therefore, we argue that if an ROV firm is in the expanding stage of its life cycle, its managers will most likely respond to market overvaluation by increasing discretionary expenses, but high discretionary expenses would not be observed for mature and stagnant ROV firms. In the case of SOV firms, we predict that they would not increase discretionary expenses regardless of where they are in the business cycle, because otherwise their reported earnings will be too low compared to market expectations and this would lead to a considerable fall in share price. We obtain evidence in line with

\footnotetext{
${ }^{1}$ In section 4.4, we also use other cut-off points and show that the main findings do not qualitatively change.
} 
our hypotheses, showing that abnormally high discretionary expenses are mainly observed in ROV firms that are in the expanding phase of their life cycle. Therefore, the evidence supports the explanation that the higher than normal discretionary expenses reported by ROV firms is not caused by a deliberate attempt to engage in REM. Overall, the evidence supports the view that, while managers of SOV firms inflate earnings using both AEM and REM, managers of ROV firms do not manage earnings.

We contribute to the literature in several ways. First, by making the distinction between SOV and ROV firms, the analysis in the paper enhances our understanding of whether and how overvaluation triggers earnings management. Compared to Badertscher (2011), for example, our focus is on the degree of overvaluation, while Badertscher mainly asks if the duration of the overvaluation drives the earnings management behaviour of managers in overvalued firms. Through our analysis, we are able to show that the behaviour of managers of SOV firms mainly drives the evidence documented by earlier studies that overvalued firms inflate earnings to sustain overvaluation (Chi and Gupta, 2009; Houmes and Skantz, 2010; Badertscher, 2011). Second, we provide evidence on how overvalued firms choose between AEM and REM to respond to overvaluation. Managers of SOV firms are found to engage in both incomeinflating AEM and value-destroying REM simultaneously. This evidence is new and contributes to the on-going debate on how managers choose between AEM and REM. While the existing literature generally suggests that AEM and REM are used as substitutes (Zang, 2012; Badertscher, 2011), our evidence shows that, if a firm is substantially overvalued, both AEM and REM are used simultaneously to cover up the substantial overvaluation. In contrast, managers of ROV firms do not engage in AEM and appear to refrain from REM, depending on the firm's life cycle phase.

The rest of the paper is organized as follows. Section 2 reviews the related literature before the hypotheses are determined and developed. Section 3 describes the data and main methodologies used to test the hypotheses. Section 4 presents and discusses the results, while section 5 concludes.

\section{Related literature, motivation and hypotheses}

Jensen (2005) analyses the incentives and pressures faced by managers of overvalued firms that could lead to value-destroying earnings management. Managers, whose wealth is often tied to the firm's 
performance, have an incentive to maximize the performance-linked component of their compensation, such as bonuses and stock options. In addition, existing evidence suggests that neglecting the market's expectations results in substantial adverse effects on managers' compensation (Matsunaga and Park, 2001) and significantly large negative abnormal returns (Skinner and Sloan, 2002). Because overvalued firms are unable to deliver a performance that meets the market's expectations, Jensen (2005) conjectures that managers of overvalued firms would engage in earnings management to inflate earnings.

Following Jensen's (2005) prediction, prior studies have empirically investigated how managers of overpriced firms manage earnings. Chi and Gupta (2009) measure firm-specific and industry-level valuation errors using a valuation model developed by Rhodes-Kropf et al. (2005). They find evidence that valuation errors are positively related to discretionary accruals in the year following the overpricing of the firm's equity. Houmes and Skantz (2010) present evidence that managers of overvalued firms, identified as those with a high prior year price-to-earnings ratio and/or high prior year abnormal returns, use discretionary accruals to manage earnings upwards in the year following the firm's overvaluation. Badertscher (2011), following Frankel and Lee (1998), estimates the firms' intrinsic value with a valuation model based on the residual income approach (Edwards and Bell, 1966; Ohlson, 1995) and uses the price-to-value ratio to identify overvaluation. Badertscher (2011) finds that the longer the period of overvaluation, the more likely it is that managers will engage in earnings management behaviour. Overvaluation is also shown to trigger different earnings management techniques depending on its duration. AEM is used extensively in the early years of overvaluation, but after three years REM becomes the more likely method. In addition, Badertscher (2011) also finds that the longer a firm is overvalued, the more likely it is that the managers will engage in earnings management that later requires restatements.

Although the established evidence seems consistent with the agency cost theory of overvalued equity proposed by Jensen (2005), there are aspects of Jensen's hypothesis that remain unexplored. One of the limitations of the extant literature relates to the identification of overpriced firms. Jensen (2005) emphasizes that his explanation is only applicable to substantially overvalued firms. Nevertheless, most 
of the existing literature testing Jensen's hypothesis does not directly test the behaviour of such substantially overvalued firms. For example, Badertscher (2011) defines overvalued firms as all firms that belong to the top quintile ranked by the price-to-value ratio. He finds that managers of overvalued firms defined in this way manage earnings to sustain the overvaluation. However, it is possible that firms classified as overvalued using the above approach may not all be substantially overvalued in Jensen's (2005) terms. Jensen (2005, p.10) believes that managers of substantially overvalued firms often "perceive it is impossible for them to meet the performance requirements to justify the current price of their equity" and "they knew with great certainty that their firm was overvalued". In reality, Badertscher's (2011) approach captures a wide group of firms experiencing different degrees of overvaluation. It is an interesting question whether we will observe different managers' behaviour in this group, depending on the degree of the equity's overvaluation. This is a common issue among studies testing Jensen's hypothesis (Chi and Gupta, 2009; Houmes and Skantz, 2010).

In documenting that the duration of overvaluation significantly drives earnings management, Badertscher (2011) also makes an important contribution by providing evidence consistent with managers of overvalued firms using AEM and REM as substitutes. In particular, he finds that managers tend to use AEM in the first three years of overvaluation, followed by REM after overvaluation has persisted for three years. It is a well-established finding in the empirical literature that managers of overvalued firms tend to engage in AEM in the year following overvaluation (Chi and Gupta, 2009; Houmes and Skantz, 2010). However, Badertscher's (2011) finding that managers of overvalued firms do not engage in REM in the year following overvaluation calls for further scrutiny. In particular, it is questionable whether the managers of a substantially overvalued firm would be able to choose the less costly AEM over the more value-destroying REM, since they would need a large inflation of earnings to successfully maintain the overvaluation. Therefore, we investigate whether AEM and REM are only substitutes for ROV firms and not for SOV firms. We hypothesize that, if a firm is substantially overvalued, both AEM and REM are used simultaneously to inflate earnings in line with the market's expectations. 
The above arguments motivate us to make a distinction between SOV and ROV firms and to empirically investigate the extent to which the degree of overvaluation would affect the managers' engagement in different earnings management strategies. Given the heavy cost of not fulfilling the market's expectations (Matsunaga and Park, 2001; Skinner and Sloan, 2002), we expect that managers of both SOV and ROV firms would take actions to sustain market mispricing. Since SOV firms are unlikely to be able to meet the market's expectations (Jensen, 2005), we predict that managers of SOV firms would need to inflate earnings artificially. While AEM is less costly than REM, it is not always possible for managers of SOV firms to achieve the desired level of earnings by using only AEM because of the scrutiny of the Board of Directors and external auditors, as well as the reversing nature of accruals. In contrast, REM is more defensible and could be deployed when room for using AEM is restricted. Nevertheless, it is important to note that, unlike AEM, which only involves manipulating figures in the books, REM is economically costly and thus it destroys value. Although previous evidence suggests that AEM and REM are used as substitutes, Badertscher (2011) finds that REM is only used once AEM has been extensively used and further engagement in AEM may be difficult to conceal. Managers of SOV firms are under pressure to avoid the market detecting the substantial gap between the market's high expectations and the performance the firms could deliver. In this context, they are likely to employ all available earnings management tools. Therefore, we predict that managers of SOV firms would inflate earnings using both AEM and REM. We argue that, if managers of SOV firms were to use only AEM to mask the substantial overvaluation, the magnitude of discretionary accruals would become large enough to attract scrutiny from the Board and auditors. Thus, our first hypothesis is as follows:

\section{H1: Substantially overvalued (SOV) firms engage in income-increasing accruals-based (AEM) and real (REM) earnings management.}

We argue that managers of ROV firms would behave differently, because it is less likely for managers of ROV firms to think that their firms are overvalued to the point of being unable to deliver in line with the market's expectations. Since managing earnings to sustain overvaluation is costly for both the firms and their managers (Jensen, 2005; Badertscher, 2011), unless managers firmly believe that 
they will not be able to deliver the performance expected by the market, it is unlikely that they would resort to artificially inflating earnings. In addition, using earnings management to sustain overvaluation tends to require increasingly more earnings management in subsequent periods due to the reversing nature of accruals. Thus, we predict that managers of ROV firms avoid engaging in earnings management as follows:

\section{H2: Relatively overvalued (ROV) firms do not engage in income-increasing accruals-based} (AEM) and real (REM) earnings management.

\section{Data and Methodology}

\subsection{Sample selection}

We use a sample of UK ordinary stocks listed on the London Stock Exchange during the period from 1995 to 2012. All data were downloaded from Datastream, except for external auditors, which were sourced from Bloomberg. Data from Bloomberg were merged with Datastream via the International Securities Identification Number (ISIN). To avoid survivorship bias, both live and dead stocks were selected. Financial and utility firms were excluded. Firms that had more than one type of ordinary share were also excluded to avoid problems with apportioning firm-level earnings to each type of share. The final sample was derived after applying the following additional restrictions. First, stocks whose market-to-book ratios were negative were excluded to avoid problems associated with interpreting negative book values in terms of market valuation. Second, to avoid tiny stocks that could potentially inflate the scaled variables, stocks with initial total assets of less than $£ 1$ million were also dropped. Finally, we exclude observations with missing data for any of the variables used in the main analysis. The final sample comprises 11,851 firm-year observations. All continuous variables are winsorized at the $1^{\text {st }}$ and $99^{\text {th }}$ percentiles to mitigate the influence of outliers.

\section{2. $\quad$ Proxies for earnings management}

We use discretionary accruals (Ab_AC) as a proxy for AEM. Ab_AC is estimated as the signed residual of the regression specified using the cross-sectional version of the modified-Jones model, in 
which total accruals are calculated using the cash flow approach (Jones, 1991; Dechow et al., 1995)². To empirically proxy for REM, we estimate abnormal discretionary expenses following Roychowdhury $(2006)^{3}$. All regressions are run within each industry-year with at least six observations using Datastream's level-six industry classifications ${ }^{4}$. Roychowdhury's (2006) measure of abnormal discretionary expense is multiplied by -1 to derive the measure of abnormal discretionary expense (Ab_DEX) so that a positive value indicates income-increasing earnings management by cutting discretionary expenses.

\subsection{Identification of substantially overvalued (SOV) and relatively overvalued (ROV) firms}

Chi and Gupta (2009) adopt the valuation model developed by Rhodes-Kropf et al. (2005) to estimate the firms' intrinsic value. They also find evidence that trading strategies that take long positions in under-priced stocks and short positions in over-priced stocks can generate significant abnormal returns for up to three years after portfolio formation. Such evidence confirms that the valuation errors estimated using the Rhodes-Kropf et al.'s (2005) approach can indeed capture some market mispricing. Badertscher (2011) also employs the Rhodes-Kropf et al.'s (2005) approach in a robustness test.

We follow Chi and Gupta (2009) and Badertscher (2011) in employing the Rhodes-Kropf et al.'s (2005) approach to estimate the firms' intrinsic value. In each year, firms in the same level-six industry

\footnotetext{
${ }^{2}$ Despite recent criticisms that accrual models, such as the one used in this paper, might be misspecified (Ball, 2013; Owens et al., 2017), the Modified Jones model is still one of the most popularly used models to empirically proxy for earnings management. To mitigate the concerns about model misspecification, we replicate the main analysis using some variations of the modified-Jones model, including the following: (i) suppressing the intercept; (ii) using the balance sheet approach to estimate total accruals; and (iii) using the original Jones model. Unreported results show that none of the main conclusions of the paper qualitatively change when different accrual models are used.

${ }^{3}$ Roychowdhury (2006) also develops measures for sales and production manipulation. As noted by Roychowdhury (2006), sales and production manipulation would negatively affect abnormal cash flow, while a cut in discretionary expense to inflate earnings would lead to higher abnormal cash flow. The opposing effects make it difficult to interpret the results, especially if the three measures are employed together. In addition, production manipulation is only available to manufacturing firms. During our sample period, Rhodes (2005) reports that manufacturing firms contribute only $14 \%$ of the UK's Gross Value Added in 1997, and the contribution declines consistently to reach $9.9 \%$ in 2012 . Therefore, constraining the sample to only manufacturing firms would impair the implications of the paper for non-manufacturing firms, which play a more important role in the UK. For these reasons, we do not examine sales and production manipulation in this paper. ${ }^{4}$ See the Appendix for further details.
} 
in Datastream are pooled together and the following regression is estimated for each industry-year with at least 6 observations:

$$
m_{i, t}=\alpha_{0 j, t}+\alpha_{1 j, t} b_{i, t}+\alpha_{2 j, t} n i_{i, t}^{+}+\alpha_{3 j, t} I_{(<0)} n i_{i, t}^{+}+\varepsilon_{i, t}
$$

where $\mathrm{m}_{\mathrm{i}, \mathrm{t}}$ is the $\log$ of the market value of firm $i$ at the end of fiscal year $t ; \mathrm{b}_{\mathrm{i}, \mathrm{t}}$ is the $\log$ of the book value of firm $i$ in year $t$; $\mathrm{ni}_{\mathrm{i}, \mathrm{t}}^{+}$is the $\log$ of the absolute value of the net income of firm $i$ in year $t ; \mathrm{I}_{(<0)}$ is a dummy variable that takes the value of one if net income is negative and zero otherwise.

The intrinsic value of a firm, denoted by $v\left(\theta_{i, t} ; \alpha_{j, t}\right)$, where $\theta_{i, t}$ represents the fundamentals of firm $i$ in year $t$, and $\alpha_{j, t}$ are contemporaneous valuation multiples of industry $j$ in year $t$, is calculated as the predicted value of equation (1) using the estimated coefficients from the corresponding industryyear regression, as follows:

$$
v\left(\theta_{i, t} ; \alpha_{j, t}\right)=\widehat{\alpha}_{0 j, t}+\widehat{\alpha}_{1 j, t} b_{i, t}+\widehat{\alpha}_{2 j, t} n i_{i, t}^{+}+\widehat{\alpha}_{3 j, t} I_{(<0)} n i_{i, t}^{+}
$$

We calculate the means of $\hat{\alpha}_{0}, \hat{\alpha}_{1}, \hat{\alpha}_{2}$ and $\hat{\alpha}_{3}$ across industry-years and the t-statistics using the standard errors of the means. The untabulated results show that the means of $\hat{\alpha}_{0}, \hat{\alpha}_{1}, \hat{\alpha}_{2}$ and $\hat{\alpha}_{3}$ across industry-years are $1.54,0.59,0.40$ and -0.05 , respectively, and they are all significant at the $1 \%$ level. All the signs, magnitude and statistical significance of the coefficients are comparable to those reported by Rhodes-Kropf et al. (2005). The adjusted $\mathrm{R}^{2}$ is $88 \%$, which is again comparable to that reported in Rhodes-Kropf et al. (2005). The unreported results also show that on an industry-by-industry basis, there are no significantly large or small coefficient values which could potentially bias the means as reported. Because equation (2) gives intrinsic values in log form, we convert those intrinsic values into sterling value and denote them as FIV. To measure market mispricing, we use the price-to-value ratio, denoted as FVE, which is calculated as the market value of equity divided by FIV.

SOV and ROV firms are then identified as follows. For each industry-year, all firms are ranked into five quintiles based on their FVE. The top quintile, which includes the firms that are most overvalued, contains both SOV and ROV firms. We then create FSOV as the indicator of SOV firms 
within this top quintile of firms sorted by FEV and define FSOV as a dummy variable that takes the value of one if a firm's FVE is higher than or equal to the $95^{\text {th }}$ percentile of the corresponding industryyear, and zero otherwise. The indicator of ROV firms, denoted as FROV, is a dummy variable that takes the value of one if a firm belongs to the top quintile sorted by FVE but is not an SOV firm (i.e., those firms with an FVE higher than or equal to the $80^{\text {th }}$ percentile but smaller than the $95^{\text {th }}$ percentile), and zero otherwise. $^{5}$

\subsection{Control variables}

(i) Size, growth opportunities, profitability, leverage and operating cash flows

Firms of different sizes face different costs and incentives to manipulate earnings (Watts and Zimmerman, 1990; Lang and Lundholm, 1993; Dechow and Dichev, 2002). Earnings management could also be dependent on the levels of growth opportunities (Roychowdhury, 2005; Chi and Gupta, 2009) and profitability (Dechow et al., 1995). Moreover, debts usually come with restrictions, which in turn are often tied to the firm's performance. For example, Houmes and Skantz (2010) have shown that earnings management is related to financial leverage. In addition, Dechow et al. (1995) found that discretionary accruals are negatively related to operating cash flows. Indeed, most of the previous studies on earnings management control for size, growth opportunities, profitability, financial leverage and operating cash flows (Becker et al., 1998, Roychowdhury, 2006, Badertscher, 2011, Zang, 2012).

We follow the extant literature and control for these factors. Industry-adjusted firm size, denoted as aSIZE, is used to control for size and is calculated as the deviation of the log of the market value of equity at fiscal year-end from the corresponding industry-year median. Henceforth, we use an italic ' $a$ ' prefix to name variables that are industry-adjusted by subtracting the corresponding industry-year median as described above. Growth opportunities are proxied by the value-to-book ratio, VB, measured as FIV divided by the book value of equity. To proxy for profitability, the industry-adjusted return-onassets ratio, $a \mathrm{ROA}$, is used, where ROA is calculated as the net income available to common

\footnotetext{
${ }^{5}$ We acknowledge that our approach to identify SOV and ROV firms is somewhat arbitrary. Please see section 4.4. for a robustness test to mitigate this concern.
} 
shareholders scaled by initial total assets. We control for leverage using $a$ LEV, where LEV is the ratio of total debts to total assets. Since there is no consistent evidence in the literature regarding the sign of these factors, we make no predictions on the sign. Finally, $a \mathrm{CFO}$ is introduced to control for the welldocumented negative relationship between discretionary accruals and operating cash flows, where CFO is the ratio of operating cash flows to sales. $a \mathrm{CFO}$ is only used in the AEM regression and is predicted to have a negative sign.

\section{(ii) Past use of AEM}

Because of the reversing nature of accruals, use of AEM in the past may constrain a firm from further engaging in AEM. In the literature, net operating assets are often used as a measure of a firm's past AEM activity and it has been shown that firms with high net operating assets are less likely to further engage in AEM (Barton and Simko, 2002). We use $a$ BLOAT to control for a firm's past use of AEM and include it in both the AEM and REM regressions, where BLOAT is measured as shareholders' equity plus total debts minus cash and short-term investment scaled by sales. Because higher net operating assets constrain AEM, which in turn implies more REM activity since AEM and REM can be used as substitutes (Zang, 2012), $a$ BLOAT is expected to have a negative sign in the AEM regression and a positive sign in the REM regression.

\section{(iii) Competition}

Deviations from optimal business decisions do not come without costs, and these costs vary depending on the industry and on how competitive a firm is within its industry. Firms in less competitive industries and firms that are relatively more competitive face lower costs of REM activity. We use the Herfindahl index, denoted as HERFINDAHL, to proxy for the level of competition in the industry. Each year, HERFINDAHL is calculated as the sum of the squared market shares of all firms in the industry, where the market share of a firm is its sales scaled by the total sales of all firms in the industry. Moreover, to proxy for the firm industry-relative competitiveness, M_SHARE is calculated as the percentage of a firm's sales to the total sales of its industry (Zang, 2012). Because low industry-level competitiveness and high firm-specific relative competitiveness could decrease the cost of REM, both 
HERFINDAHL and M_SHARE are expected to be positive in the REM regression. Neither HERFINDAHL nor M_SHARE are used in the AEM regression.

\section{(iv) Financial distress}

Firms in financial distress face more pressure to manage earnings. García Lara et al. (2009) find that failed firms engage in both AEM and REM in the years leading to the failure. Zang (2012) argues that it is costlier for financially distressed firms to engage in REM and finds that firms would employ more AEM than REM in response to financial distress. Badertscher (2011) also finds that less distressed firms use more REM. Thus, we also control for financial distress. We follow García Lara et al. (2009) to estimate the probability of failure using the bankruptcy prediction model designed for the UK market by Charitou et al. (2004):

$$
P O F=\frac{1}{\left(1+e^{-z}\right)}
$$

and: $-Z=-7.1786+12.3826 x_{1}-20.9691 x_{2}-3.0174 x_{3}$

where POF is the probability of failure; $x_{1}$ is total liabilities divided by total assets; $x_{2}$ is earnings before interest and taxes divided by total liabilities; $x_{3}$ is cash flows from operations divided by total liabilities.

Based on the method used in Zang (2012), we include POF in both AEM and REM regressions to control for financial distress. A higher POF value implies more financial distress, which increases the cost of engaging in REM and encourages managers to use AEM as a substitute. Following this line of argument, we predict POF to be negatively correlated with abnormal discretionary expenses but positively correlated with discretionary accruals.

\section{(v) Big bath practice}

The big bath practice refers to extreme earnings management behaviour where managers intentionally book large losses into the current period, possibly to boost future earnings. It is well 
documented that firms tend to register large write-offs in periods when the managers find it difficult to avoid a loss (Christensen et al., 2008). We account for this practice by introducing two control variables. The first variable, LOSS_FIRM, is a dummy variable that takes the value of one if a firm's net income is negative, and zero otherwise. The second variable, LOSS_IND, is a dummy variable that takes the value of one if the average net income of all firms in an industry is negative, and zero otherwise. LOSS_FIRM and LOSS_IND are expected to have negative signs in both the AEM and REM regressions.

\section{(vi) External auditors}

External auditors, whose aim is to assure the true and fair view of financial statements, play an important role in constraining AEM. Existing evidence suggests that AEM is lower in firms audited by Big 4 auditors $^{6}$ (Becker et al., 1998; Francis et al., 1999). Given that AEM and REM are used as substitutes, if a Big-4 auditor constrains a firm from using AEM, the firm would be more likely to resort to REM, which involves business judgement over the discretion of managers but gives auditors less power of interference. We, therefore, control for the quality of external auditors by introducing a dummy variable, BIG4, which takes the value of one if a firm is audited by one of the Big 4 auditors, and zero otherwise. Since the presence of a Big-4 auditor would constrain AEM and divert the firms towards using REM as a substitute, we predict BIG4 to have a negative sign in the AEM regression and positive sign in the REM regression.

\subsection{The baseline regressions}

Zang (2012) argues that managers use REM before fiscal year-end. In this way, they are able to see if the desired earnings have been achieved before adjusting the level of AEM accordingly. We follow Zang (2012) and estimate the AEM and REM regressions jointly using a recursive equation

\footnotetext{
${ }^{6}$ Depending on the time period, we could refer to the Big 5 or 6 audit firms. Hereafter, in the interest of brevity, we will refer to the Big 4.
} 
system to capture this sequence of decisions with the expected and unexpected components of REM added into the AEM regression:

$$
\begin{aligned}
A b_{-} D E X_{i, t} & =\alpha+\beta_{1}\left(\text { FSOV }_{i, t-1}\right)+\beta_{2}\left(\text { FROV }_{i, t-1}\right)+\beta_{3}\left(\operatorname{aSIZE}_{i, t-1}\right)+\beta_{4}\left(\text { VB }_{i, t-1}\right)+ \\
& \beta_{5}\left(\text { aROA }_{i, t}\right)+\beta_{6}\left(\text { aLEV }_{i, t-1}\right)+\beta_{7}\left(\text { aBLOAT }_{i, t-1}\right)+\beta_{8}\left(\text { HERFINDAHL }_{i, t}\right)+ \\
& \beta_{9}\left(\text { M_SHARE }_{i, t}\right)+\beta_{10}\left(\text { POF }_{i, t}\right)+\beta_{11}\left(\text { LOSS_FIRM }_{i, t}\right)+\beta_{12}\left(\text { LOSS_IND }_{i, t}\right)+ \\
& \beta_{13}\left(\text { BIG4 }_{i, t}\right)+\varepsilon_{i, t}
\end{aligned}
$$

$A b_{-} A C_{i, t}=\alpha+\beta_{1}\left(\operatorname{FSOV}_{i, t-1}\right)+\beta_{2}\left(F_{R O V}, t-1\right)+\beta_{3}\left(\operatorname{aSIZE}_{i, t-1}\right)+\beta_{4}\left(V_{B_{i, t-1}}\right)+$

$$
\begin{aligned}
& \beta_{5}\left(\text { aROA }_{i, t}\right)+\beta_{6}\left(\text { aLEV }_{i, t-1}\right)+\beta_{7}\left(\text { aCFO }_{i, t}\right)+\beta_{8}\left(\operatorname{aBLOAT}_{i, t-1}\right)+\beta_{9}\left(\text { POF }_{i, t}\right)+ \\
& \beta_{10}\left(\text { LOSS_FIRM }_{i, t}\right)+\beta_{11}\left(\operatorname{LOSS}_{-} I N D_{i, t}\right)+\beta_{12}\left(\text { BIG4 }_{i, t}\right)+\beta_{13}\left(P A B D E X_{i, t}\right)+ \\
& \beta_{12}\left(\text { UABDEX }_{i, t}\right)+\varepsilon_{i, t}
\end{aligned}
$$

where PABDEX is the predicted value of equation (4); UABDEX is the residual of equation (4); and all other variables are described in sections 3.2, 3.3 and 3.4.

The above regressions allow a comparison of the levels of REM and AEM of SOV and ROV firms versus the rest of the sample. Given the concerns regarding using panel data (e.g., Thompson, 2009; Petersen, 2009; Gow et al., 2010), two-way clustered standard errors that are robust across both time and firm dimensions are used. The coefficients of interest are $\beta_{1}$ and $\beta_{2} . H 1$ predicts that $\beta_{1}$ is significantly positive, while $H 2$ predicts that $\beta_{2}$ is insignificant in both equations (4) and (5).

\section{Descriptive statistics and empirical results}

\subsection{Descriptive statistics and correlations}

Table 1 reports the descriptive statistics of the main variables. The median price-to-value ratio, FVE, which we use as a proxy for market mispricing, is 0.9736 , showing that approximately half of the sample firms are overvalued, and the other half are undervalued. The averages of Ab_AC and Ab_DEX are small, but not zero, because of the winsorization. All of the industry-adjusted variables (i.e., $a$ SIZE, 
$a \mathrm{ROA}, a \mathrm{LEV}, a \mathrm{CFO}, a \mathrm{BLOAT})$ have a median of zero, as expected due to the way they are constructed. Overall, the descriptive statistics suggest no serious concerns and are comparable to other studies (Garcia Lara et al., 2009; Athanasakou et al., 2009; Athanasakou et al., 2011).

\section{[INSERT TABLE 1 HERE]}

Table 2 reports the Pearson correlation coefficients between the main variables. FVE is negatively and significantly related to Ab_DEX (-0.121), while the correlation between FVE and Ab_AC is insignificant at the 5\% level, although it is negative (-0.009). Among the control variables, most of the expected correlations with the proxies for earnings management are observed, but there is no significant correlation between the explanatory variables.

\section{[INSERT TABLE 2 HERE]}

\subsection{Univariate analysis}

We first examine the characteristics of firms with different degrees of market mispricing. Within each industry-year, firms are sorted by FVE at the end of year $t-1$ into five quintiles, namely, Groups 1 to 5. Within the top quintile, Group 5, firms are further divided into four smaller groups. Groups 6, 7 and 8 include ROV firms, which are firms that respectively have an FVE larger than or equal to the corresponding industry-year $80^{\text {th }}$ percentile, but smaller than the $85^{\text {th }}$ percentile (Group 6); are larger than or equal to the corresponding industry-year $85^{\text {th }}$ percentile, but smaller than the $90^{\text {th }}$ percentile (Group 7); and are larger than or equal to the corresponding industry-year $90^{\text {th }}$ percentile, but smaller than the $95^{\text {th }}$ percentile (Group 8). Group 9 includes SOV firms, which are those that have an FVE larger than or equal to the corresponding industry-year $95^{\text {th }}$ percentile. Table 3 reports the means of the earnings management proxies, market mispricing and some selected fundamentals for each group, together with the results of the t-tests comparing the means between: (i) ROV firms and the rest of the sample; (ii) SOV firms and the rest of the sample; and (iii) SOV and ROV firms.

[INSERT TABLE 3 HERE] 
The classification scheme we use results in 1,701 observations being classified as ROV firms and 634 observations as SOV firms. The evidence in Table 3 suggests that overvalued firms, both SOV and ROV, are significantly larger in size, measured by sales, total assets and market value of equity, than the rest of the sample. However, there is no evidence that SOV firms are larger than ROV firms as the differences in sales, total assets and market value of equity are all statistically insignificant. The FVE of SOV firms is higher than that of ROV firms by 1.1785 (significant at $1 \%$ level). Across the five quintiles sorted by FVE (i.e., Group 1 to Group 5), there is no clear pattern in the use of AEM and REM. Focussing on the top quintile, that is the overvalued firms in Group 5, the means of Ab_AC and Ab_DEX are positive ( 0.0145 and 0.0195 , respectively), suggesting a positive association between income-increasing earnings management and overvaluation in line with the existing literature (Chi and Gupta, 2009; Houmes and Skantz, 2010; Badertscher, 2011). When the top quintile is decomposed into FSOV and FROV, the mean Ab_AC of SOV firms is significantly higher compared to that of either ROV firms (the difference is 0.0322 , significant at the $1 \%$ level) or the rest of the sample (the difference is 0.0372 , significant at $1 \%$ level). Similarly, the mean Ab_DEX of SOV firms is significantly higher than that of either ROV firms (the difference is 0.1184 , significant at the $1 \%$ level) or the rest of the sample (the difference is 0.0704 , significant at the $1 \%$ level). This initial evidence suggests that SOV firms inflate earnings using both AEM and REM. In contrast, the mean Ab_AC of ROV firms is not significantly higher than the rest of the sample (the difference is 0.005 and is statistically insignificant) and ROV firms exhibit lower Ab_DEX than the rest of the sample (the difference is -0.0479 , significant at $1 \%$ level). This evidence suggests that ROV firms do not inflate earnings.

Overall, the initial evidence presented in this section supports the hypothesis that SOV firms inflate earnings using both AEM and REM, while ROV firms do not engage in income-increasing earnings management. In the next section, we build on these findings by further considering other known drivers of earnings management within a multivariate regression framework. 


\subsection{Regression Analysis}

Table 4 reports the results of estimating equations (4) and (5). Focusing first on the key variables of interest, FSOV and FROV, the coefficient of Ab_AC on FSOV is positive and statistically significant (0.0407, significant at the $1 \%$ level), suggesting that SOV firms inflate earnings using AEM. Similarly, the coefficient of Ab_DEX on FSOV is significantly positive (0.0575, significant at the $1 \%$ level). These results suggest that SOV firms make use of both AEM and REM to inflate earnings to justify the high market valuation. When Ab_AC is the dependent variable, the coefficient of FROV is -0.0103 and is statistically insignificant. The coefficient of Ab_DEX on FROV is negative (-0.0503) and significant at the $1 \%$ level. These results, taken together with the significantly positive coefficients of Ab_AC and $\mathrm{Ab} \_\mathrm{DEX}$ on FSOV, suggest that the evidence in the extant literature of income-increasing earnings management by overvalued firms (Chi and Gupta, 2009; Houmes and Skantz, 2010; Badertscher, 2011) is mainly driven by SOV firms. In contrast, ROV firms, although overvalued by the market, refrain from inflating earnings. These findings support both hypotheses $\mathrm{H} 1$ and $\mathrm{H} 2$.

\section{[INSERT TABLE 4 HERE]}

Further consideration of the results in Table 4 show that VB, which captures growth opportunities, is negatively related to Ab_DEX (-0.0081, significant at the $1 \%$ level), suggesting that firms with more growth opportunities tend to have higher discretionary expenditure. The coefficient of $\mathrm{Ab} \_\mathrm{AC}$ on $a \mathrm{CFO}$ is negative $(-0.007)$ and statistically significant $(1 \%$ level), as predicted. $a \mathrm{BLOAT}$ exhibits a negative relation with Ab_AC (-0.0024, significant at the $10 \%$ level), which implies that the past use of accruals does play a significant role in constraining further engagement in AEM. $a$ BLOAT is also positively related to Ab_DEX (0.0021, significant at the $1 \%$ level), suggesting that managers tend to switch to REM when further use of AEM could be detected. The coefficient on BIG4 is significantly negative in the Ab_AC regression (-0.007, significant at the 5\% level), which shows that the Big-4 audit firms constrain the use of AEM. The coefficient of Ab_AC on UABDEX is significantly negative (0.0127 , significant at the $1 \%$ level) supporting the existing evidence that a firm would decide the level 
of AEM after observing the realized effect of REM on reported earnings (Zang, 2012). In general, most of the coefficients of the control variables are consistent with earlier predictions ${ }^{7}$.

While the evidence supports both hypotheses $\mathrm{H} 1$ and $\mathrm{H} 2$, the negative and statistically significant coefficient of Ab_DEX on FROV needs further investigation. We believe that the abnormally high discretionary expenses exhibited by ROV firms are more the result of changing real operation activities in accordance with the business life cycle than a deliberate attempt to depress earnings. In the expanding phase of their firms' life cycle, managers are motivated to invest to take advantage of the available growth opportunities and deter entry from potential competitors (Dickinson, 2011). Being overvalued in this stage has important implications. We argue that managers of SOV firms in the expanding phase are reluctant to invest more if such investments lead to lower reported earnings (such as research and development or other discretionary expenses), because this would trigger large price corrections. However, if a firm is only relatively overvalued in the expanding phase, managers are willing to spend on investments that could enhance future value, even if it means lower reported earnings. Hence, high abnormal discretionary expenses of ROV firms in the expanding period are not interpreted as a deliberate attempt to manage earnings, but rather as a decision justified by the currently experienced business life cycle.

To test for the above inferred behaviour, we introduce CYCLE as a variable that captures the firm-level business life cycle. CYCLE is constructed as follows. First, in each industry-year, we sort all firms into three terciles using sales growth (defined as the arithmetic growth of net sales compared to last year) and create a variable named SG_CYCLE, which is assigned values of 1, 2 or 3 if a firm belongs to the top, middle or bottom tercile, respectively. The process is repeated to obtain CAPEX_CYCLE, which is assigned a value of 1, 2 or 3 if a firm belongs to the top, middle or bottom

\footnotetext{
${ }^{7}$ Since there are many control variables, an immediate concern is multicollinearity. Table 2 shows that there is no considerable correlation between the explanatory variables. We also calculate the variance inflation factors (VIF) for all the predictors in equations (3) and (4). The unreported results show that none of the VIFs is above 3.92, except for the VIF for PABDEX (13.07) in equation (4), mostly due to its high correlation with aROA (Pearson correlation coefficient is 0.792 , significant at the $1 \%$ level). To mitigate the concern, we re-estimate equation (4) without aROA on the right-hand side, and the main results do not qualitatively change (the VIF for PABDEX drops to 2.46). As a last check, equations (3) and (4) are re-estimated using only aSIZE, VB and $a$ ROA as control variables. The unreported results show that when using this specification, the main conclusions are qualitatively the same.
} 
tercile sorted by capital expenditures, respectively; DIV_CYCLE, which is assigned a value of 1,2 or 3 if a firm belongs to the bottom, middle or top tercile sorted by cash dividends, respectively; and AGE_CYCLE, which is assigned a value of 1, 2 or 3 if a firm belongs to the bottom, middle or top tercile sorted by firm age, respectively. CYCLE is then calculated as the sum of SG_CYCLE, CAPEX_CYCLE, DIV_CYCLE and AGE_CYCLE. The existing literature shows that firms in the expanding (mature/stagnant) phase generally have high (low) sales growth and capital expenditures and low (high) cash dividends and age (Anthony and Ramesh, 1992; Dickinson, 2011). By construction, CYCLE is an integer ranging from 4 to 12, and lower (higher) values suggest that firms are in the expanding (mature/stagnant) phase of their life cycle.

Dickinson (2011) argues and provides evidence that most firms on the market would be mature firms, because expanding firms eventually become mature, and once they reach the mature phase, their managers aim at maintaining stability to defer entering the stagnant phase. Following this line of argument, we arbitrarily define firms with a CYCLE of 7 or lower as expanding firms. Therefore, 2,936 observations, equivalent to $24.8 \%$ of the sample, are classified as expanding firms, and 8,915 observations, $75.2 \%$ of the sample, as mature firms, which is comparable to previous studies using different classification schemes (Anthony and Ramesh, 1992; Dickinson, 2011). We define EXPAND as a dummy variable, which takes the value of one if CYCLE is 7 or smaller, and zero otherwise. Using a similar approach to the main test, the following regressions are then estimated jointly using a recursive equation system as follows:

$$
\begin{aligned}
& A b_{-} D E X_{i, t}=\alpha+\beta_{1}\left(\text { FSOV }_{i, t-1}\right)+\beta_{2}\left(F_{\text {ROV }}, t-1\right)+\beta_{3}\left(\operatorname{EXPAND}_{i, t}\right)+\beta_{4}\left(\text { FSOV }_{i, t-1} \times\right. \\
& \left.\operatorname{EXPAND}_{i, t}\right)+\beta_{5}\left(\operatorname{FROV}_{i, t-1} \times \operatorname{EXPAND}_{i, t}\right)+\beta_{6}\left(\operatorname{aSIZE}_{i, t-1}\right)+\beta_{7}\left(V_{i, t-1}\right)+ \\
& \beta_{8}\left(\operatorname{aROA}_{i, t}\right)+\beta_{9}\left(\operatorname{aLEV}_{i, t-1}\right)+\beta_{10}\left(\operatorname{aBLOAT}_{i, t-1}\right)+\beta_{11}\left(\operatorname{HERFINDAHL}_{i, t}\right)+ \\
& \beta_{12}\left(M_{-} S H A R E_{i, t}\right)+\beta_{13}\left(P O F_{i, t}\right)+\beta_{14}\left(L O S S_{-} F I R M_{i, t}\right)+\beta_{15}\left(\operatorname{LOSS}_{-} I N D_{i, t}\right)+ \\
& \beta_{16}\left(B I G 4_{i, t}\right)+\varepsilon_{i, t}
\end{aligned}
$$




$$
\begin{aligned}
& A b_{-} A C_{i, t}=\alpha+\beta_{1}\left(F_{S O V}^{i, t-1}\right)+\beta_{2}\left(F_{R O V} \operatorname{Vit}_{i, 1}\right)+\beta_{3}\left(\operatorname{EXPAND}_{i, t}\right)+\beta_{4}\left(\text { FSOV }_{i, t-1} \times\right. \\
& \left.\operatorname{EXPAND}_{i, t}\right)+\beta_{5}\left(\operatorname{FROV}_{i, t-1} \times \operatorname{EXPAND}_{i, t}\right)+\beta_{6}\left(\operatorname{aSIZE}_{i, t-1}\right)+\beta_{7}\left(V_{i, t-1}\right)+ \\
& \beta_{8}\left(a R O A_{i, t}\right)+\beta_{9}\left(a L E V_{i, t-1}\right)+\beta_{10}\left(a C F O_{i, t}\right)+\beta_{11}\left(a B L O A T_{i, t-1}\right)+\beta_{12}\left(P O F_{i, t}\right)+ \\
& \beta_{13}\left(L_{\text {LOSS_FIRM }}{ }_{i, t}\right)+\beta_{14}\left(L O S S_{-} I N D_{i, t}\right)+\beta_{15}\left(B I G 4_{i, t}\right)+\beta_{16}\left(P A B D E X_{i, t}\right)+ \\
& \beta_{17}\left(U A B D E X_{i, t}\right)+\varepsilon_{i, t}
\end{aligned}
$$

Due to the lack of an underlying economic theory that links accruals behaviour with the business life cycle (Owens et al., 2017), we make no prediction about how SOV and ROV firms engage in AEM in the expanding phase. Equation (7) is estimated and the results are reported for completeness. The main focus, however, is on equation (6), where we test if being overvalued in the expanding phase would make a difference to the firms' discretionary expenses. $\beta_{1}\left(\beta_{2}\right)$ in equation (6) captures the effect of being substantially overvalued (relatively overvalued) in the post-expanding phases on discretionary expenditure. If SOV (ROV) firms deviate from normal levels of discretionary expenses in the expanding phase, the effect is captured by $\beta_{4}\left(\beta_{5}\right)$. The results are reported in Table 5 .

\section{[INSERT TABLE 5 HERE]}

Including the business life cycle in the analysis reveals some interesting insights. EXPAND is significantly negative in the Ab_DEX regression (-0.0325 significant at the 1\% level), suggesting that firms in the expanding phase tend to report higher discretionary expenses, most likely to take advantage of available growth opportunities. However, SOV firms in the expanding phase do not report higher discretionary expenses, as the coefficient of Ab_DEX on the interaction term FSOV*EXPAND is statistically insignificant. In contrast, ROV firms in the expanding phase report significantly higher discretionary expenses than normal, as the FROV*EXPAND term exhibits a significant and negative relationship with Ab_DEX (-0.1449 significant at the 1\% level). After controlling for the abnormally high discretionary expenses of ROV firms in the expanding phase, there is no evidence that ROV firms in the post-expanding phase, which accounts for $75.2 \%$ of the sample, exhibit any deviation from normal levels of discretionary expenses, as the coefficient of Ab_DEX on FROV is statistically insignificant. The evidence suggests that ROV firms report high levels of Ab_DEX. This finding is 
mainly driven by the behaviour of firms in the expanding phase, rather than resulting from a deliberate attempt by managers to increase discretionary expenses to deflate earnings.

\subsection{Robustness tests}

(i) Alternative model to estimate market mispricing

In the main test, which follows Rhodes-Kropf et al. (2005), a firm's intrinsic value is estimated using a special form of the residual income valuation model, under the assumptions that book values and net incomes grow at constant rates, where the growth rates and costs of equity are embodied by the risk characteristics of the average firm in each industry-year. This approach is also used by Chi and Gupta (2009) in a related study that examines how managers of overvalued firms manage earnings. Badertscher (2011) also employs this approach in a robustness test. However, in the main test, Badertscher (2011) follows Frankel and Lee (1998) to estimate the firms' intrinsic value using a valuation model based on the residual income approach (Edwards and Bell, 1966; Ohlson, 1995). To see if our results hold if we adopt the valuation model in Badertscher (2011), we employ a version of the residual income approach, as proposed by Frankel and Lee (1998). In particular, we estimate the firm's intrinsic value as follows:

$$
R I V_{i, t}=B_{i, t}+\frac{\left(F R O E_{i, t}-r_{i, t}^{e}\right)}{\left(1+r_{i, t}^{e}\right)} \times B_{i, t}+\frac{\left(F R O E_{i, t}-r_{i, t}^{e}\right)}{\left(1+r_{i, t}^{e}\right) \times r_{i, t}^{e}} \times B_{i, t}
$$

where $R I V_{i, t}$ is the intrinsic value of firm $i$ at the end of year $t ; B_{i, t}$ and $F R O E_{i, t}$ are the book value of equity and the future return on equity of firm $i$ at the end of year $t$ derived from Bloomberg's BEst consensus, using the sequential process as outlined in Frankel and Lee (1998); $r_{i, t}^{e}$ is the cost of equity of firm $i$ in year $t$, estimated using the Fama and French (1993) three-factor model augmented by the momentum factor (Carhart, 1997) ${ }^{8}$.

\footnotetext{
${ }^{8}$ The data used to estimate the four-factor model, including the risk-free rate, returns on the market portfolio, size, book-to-market and momentum factors are sourced from the database made available by Gregory et al. (2013).
} 
The BEst consensus forecast is downloaded from Bloomberg and merged to the main database via ISIN. For this robustness test, we keep only firm-year observations that have sufficient data to estimate intrinsic value using equation (8) above. As a result, the sample used in this robustness test is significantly smaller than the sample in the main test and contains only 1,684 observations. The priceto-value ratio, denoted RVE, is calculated as the market value divided by RIV. Based on REV, we define RSOV and RROV firms as substantially overvalued and relatively overvalued firms, respectively, using the same method as was used for the main test. Finally, equations (4), (5), (6) and (7) are re-estimated using RSOV and RROV instead of FSOV and FROV, respectively. The results presented in Table 6 suggest that the use of an alternative way to estimate market mispricing does not qualitatively change the results.

\section{[INSERT TABLE 6 HERE]}

\section{(ii) Alternative benchmark to identify overvalued firms}

We acknowledge that the use of the $80^{\text {th }}$ and $95^{\text {th }}$ percentiles to define SOV and ROV firms in the main test, although necessary for this type of research, is arbitrary. To mitigate concerns that our results could be affected by such arbitrary benchmarks, we replicate the main test using the $67^{\text {th }}$ and $90^{\text {th }}$ percentiles. In particular, using the same methods of the main test, ROV firms are defined in this section as those with FVE larger than or equal to the $67^{\text {th }}$ percentile but smaller than the $90^{\text {th }}$ percentile and SOV firms are those with FVE larger than or equal to the $90^{\text {th }}$ percentile. Under these definitions, more firms are identified as overvalued. The results, reported in Table 7, show that the use of lower benchmarks to identify SOV and ROV firms does not change the main conclusion of our paper.

\section{[INSERT TABLE 7 HERE]}

\section{Conclusions}

While the existing literature suggests that overvaluation can trigger earnings management (Chi and Gupta, 2009; Houmes and Skantz, 2010; Badertscher, 2011), we additionally show that the degree of such overvaluation is important. By making a distinction between substantially overvalued firms 
(SOV) and relatively overvalued firms (ROV), we reveal some new insights. Using a sample of UK listed stocks for the period from 1995 to 2012, we hypothesize and find evidence that, in line with Jensen's (2005) conjecture, managers of SOV firms inflate earnings to sustain the substantial overvaluation. The evidence suggests that managers of SOV firms employ both income-increasing accruals-based and real earnings management. Second, we hypothesize that managers of ROV firms refrain from managing earnings since it would be too costly to support market expectations through earnings management. The findings confirm that managers of ROV firms do not engage in AEM. We further observe that ROV firms exhibit abnormally high discretionary expenses, but this result is driven by ROV firms in the expanding phase of their life cycle. This suggests that managers of ROV firms only increase discretionary expenses in response to the needs and pressures of expanding, rather than in a deliberate attempt to deflate earnings. Thus, the evidence suggests that ROV firms do not inflate earnings to sustain high market valuation.

Overall, the findings further clarify our understanding of capital market driven motivations for earnings management. The results presented in the paper have a number of important implications for investors who target mispriced stocks and for company boards and audit committees in supervising the firm's real operations.

\section{References}

AGARWAL, V. \& TAFFLER, R. 2007. Twenty-five years of the Taffler z-score model: does it really have predictive ability? Accounting and Business Research, 37, 285-300.

ANTHONY, J. H. \& RAMESH, K. 1992. Association between accounting performance measures and stock prices. Journal of Accounting and Economics, 15, 203-227.

ATHANASAKOU, V., STRONG, N. C. \& WALKER, M. 2009. Earnings management or forecast guidance to meet analyst expectations? Accounting and Business Research, 39, 3-35.

ATHANASAKOU, V., STRONG, N. C. \& WALKER, M. 2011. The Market Reward for Achieving Analyst Earnings Expectations: Does Managing Expectations or Earnings Matter? Journal of Business Finance \& Accounting, 38, 58-94.

BADERTSCHER, B. A. 2011. Overvaluation and the Choice of Alternative Earnings Management Mechanisms. Accounting Review, 86, 1491-1518.

BALL, R. 2013. Accounting Informs Investors and Earnings Management is Rife: Two Questionable Beliefs. Accounting Horizons, 27, 847-853. 
BARTON, J. \& SIMKO, P. J. 2002. The Balance Sheet as an Earnings Management Constraint. Accounting Review, 77, 1-27.

BECKER, C. L., DEFOND, M. L., JIAMBALVO, J. \& SUBRAMANYAM, K. R. 1998. The Effect of Audit Quality on Earnings Management. Contemporary Accounting Research, 15, 1-24.

CARHART, M. 1997. On persistence in mutual fund performance. The Journal of Finance, 52, 57-82.

CHARITOU, A., NEOPHYTOU, E. \& CHARALAMBOUS, C. 2004. Predicting corporate failure: Empirical evidence for the UK. European Accounting Review, 13, 465-497.

CHI, J. \& GUPTA, M. 2009. Overvaluation and earnings management. Journal of Banking \& Finance, 33, 1652-1663.

CHRISTENSEN, T. E., PAIK, G. H. \& STICE, E. K. 2008. Creating a Bigger Bath Using the Deferred Tax Valuation Allowance. Journal of Business Finance and Accounting, 35, 601-625.

DECHOW, P. M., SLOAN, R. G. \& SWEENEY, A. P. 1995. Detecting Earnings Management. Accounting Review, 70, 193-225.

DICKINSON, V. 2011. Cash Flow Patterns as a Proxy for Firm Life Cycle. Accounting Review, 86, 19641994.

EDWARDS, E. O. \& BELL. P. W. 1961. The Theory and Measurement of Business Income. Berkeley, CA: University of California Press.

FAMA, E. F. \& FRENCH, K. R. 1993. Common risk factors in the returns on stocks and bonds. Journal of Financial Economics, 33, 3-56.

FRANCIS, J. R., MAYDEW, E. L. \& SPARKS, H. C. 1999. The Role of Big 6 Auditors in the Credible Reporting of Accruals. Auditing, 18, 17.

FRANKEL, R. \& LEE, C. M. C. 1998. Accounting valuation, market expectation, and cross-sectional stock returns. Journal of Accounting and Economics, 25, 283-319.

GARCÍA LARA, J. M., GARCÍA OSMA, B. \& NEOPHYTOU, E. 2009. Earnings quality in ex-post failed firms. Accounting and Business Research, 39, 119-138.

GOW, I. D., ORMAZABAL, G. \& TAYLOR, D. J. 2010. Correcting for Cross-Sectional and Time-Series Dependence in Accounting Research. Accounting Review, 85, 483-512.

GREGORY, A., THARYAN, R. \& CHRISTIDIS, A. 2013. Constructing and testing alternative versions of the Fama-French and Carhart models in the UK. Journal of Business Finance and Accounting, 40, 172-214.

HOUMES, R. E. \& SKANTZ, T. R. 2010. Highly Valued Equity and Discretionary Accruals. Journal of Business Finance and Accounting, 37, 60-92.

MATSUNAGA, S. R. \& PARK, C. W. 2001. The effect of missing a quarterly earnings benchmark on the ceo's annual bonus. Accounting Review, 76, 313.

OHLSON, J. A. 1995. Earnings, book values, and dividends in equity valuation. Contemporary Accounting Research, 11, 661-687. 
OWENS, E., WU, J. S. \& ZIMMERMAN, J. L. 2017. Idiosyncratic Shocks to Firm Underlying Economics and Abnormal Accruals. Accounting Review, 92, 183-219.

PETERSEN, M. A. 2009. Estimating Standard Errors in Finance Panel Data Sets: Comparing Approaches. Review of Financial Studies, 22, 435-480.

POLK, C. \& SAPIENZA, P. 2009. The stock market and corporate investment: A test of catering theory. Review of Financial Studies, 22, 187-217.

RHODES-KROPF, M., ROBINSON, D. T. \& VISWANATHAN, S. 2005. Valuation waves and merger activity: The empirical evidence. Journal of Financial Economics, 77, 561-603.

ROYCHOWDHURY, S. 2006. Earnings management through real activities manipulation. Journal of Accounting and Economics, 42, 335-370.

SKINNER, D. J. \& SLOAN, R. G. 2002. Earnings surprises, growth expectations, and stock returns or don't let an earnings torpedo sink your portfolio. Review of Accounting Studies, 7, 289-312.

TAFFLER, R. 1983. The Assessment of Company Solvency and Performance Using a Statistical Model. Accounting and Business Research, 13, 295-307.

THOMPSON, S. 2009. Simple Formulas for Standard Errors that Cluster by Both Firm and Time. Available at SSRN: $\underline{\text { http://ssrn.com/abstract }=914002}$.

WATTS, R. L. \& ZIMMERMAN, J. L. 1990. Positive Accounting Theory: A Ten Year Perspective. Accounting Review, 65, 131-156.

ZANG, A. Y. 2012. Evidence on the Trade-Off between Real Activities Manipulation and Accrual-Based Earnings Management. Accounting Review, 87, 675-703.

\section{Appendix: Definition of variables}

$\mathbf{A b} \_\mathbf{A C}$ is discretionary accruals, measured as the deviation of actual scaled TAC from the predicted value of the following equation, which is estimated within each (two-digit SIC code) industry-year with at least 6 observations of available data, using a sample that comprises only ordinary stocks of UK firms listed on the London Stock Exchange with one type of ordinary share and a positive book value of equity, excluding financial and utilities firms:

$T A C_{i, t} / T A_{i, t-1}=\alpha+\beta_{1} 1 / T A_{i, t-1}+\beta_{2}\left(\Delta R E V_{i, t}-\Delta R E C_{i, t}\right) / T A_{i, t-1}+$ $\beta_{3} P P E_{i, t} / T A_{i, t-1}+\varepsilon_{i, t}$; where TAC is total accruals, calculated as net income before extraordinary income and after preferred dividend minus cash flow from operations (from the cash flows statements); PPE is gross plant, property and equipment; $\triangle \mathrm{REC}$ is change in receivables from last fiscal year; TA is total assets.

Ab_DEX is abnormal discretionary expense, measured as the deviation of actual scaled DEX from the predicted value of the following equation, which is estimated within each (two-digit SIC code) industryyear with at least 6 observations of available data using a sample that comprises only ordinary stocks of UK firms listed on the London Stock Exchange with one type of ordinary share and a positive book value of equity, excluding financial and utilities firms, multiplied by -1: $D E X_{i, t} / T A_{i, t-1}=\alpha+\beta_{1} 1 / T A_{i, t-1}+$ $\beta_{2} R E V_{i, t-1} / T A_{i, t-1}+\varepsilon_{i, t}$; where DEX is the discretionary expense, defined as the sum of research and development and selling and general administrative expenses. 
FIV, or $\mathbf{v}\left(\boldsymbol{\theta}_{\mathbf{i}, \mathbf{t}} ; \boldsymbol{\alpha}_{\mathbf{j}, \mathbf{t}}\right)$, is firm-specific intrinsic value, estimated using a firm's fundamentals $\left(\theta_{\mathrm{i}, \mathrm{t}}\right)$ and the contemporaneous industry valuation multiples $\left(\widehat{\alpha}_{j, t}\right)$, defined as: $v\left(\theta_{i, t} ; \alpha_{j, t}\right)=\hat{\alpha}_{0 j, t}+\hat{\alpha}_{1 j, t} b_{i, t}+$ $\hat{\alpha}_{2 j, t} n i_{i, t}^{+}+\widehat{\alpha}_{3 j, t} I_{(<0)} n i_{i, t}^{+}$; in which $\widehat{\alpha}_{\mathrm{kj}, \mathrm{t}}(\mathrm{k}=0,1,2,3)$ are from estimating the following regression within each (two-digit SIC code) industry-year with at least 6 observations of available data using a sample that comprises only ordinary stocks of UK firms listed on the London Stock Exchange with one type of ordinary share and a positive book value of equity, excluding financial and utilities firms: $m_{i, t}=$ $\alpha_{0 j, t}+\alpha_{1 j, t} b_{i, t}+\alpha_{2 j, t} n i_{i, t}^{+}+\alpha_{3 j, t} I_{(<0)} n i_{i, t}^{+}+\alpha_{4 j, t} L E V_{i, t}+\varepsilon_{i, t}$; where $\mathrm{m}$ is $\log$ of market value of equity at fiscal year-end, $\mathrm{b}$ is $\log$ of book value of equity; $\mathrm{ni}^{+}$is $\log$ of the absolute value of net income; $\mathbf{I}_{(<0)}$ is an indicator of loss, which is one if a firm's net income is negative and zero otherwise; LEV is book leverage ratio, defined as the ratio of total debts to total assets.

FVE is price-to-value ratio, estimated as market value divided by FIV.

FSOV is a dummy variable, which is one if a firm's FVE is higher than or equal to the corresponding industry-year $95^{\text {th }}$ percentile.

FROV is a dummy variable, which is one if a firm's FVE is higher than or equal to the corresponding industry-year $80^{\text {th }}$ percentile but smaller than the $95^{\text {th }}$ percentile.

$\boldsymbol{a S I Z E}$ is the deviation from the corresponding industry-year median of the log of market value at fiscal year-end.

VB is the value-to-book ratio, defined as firm-specific intrinsic values divided by book values of equity. $\boldsymbol{a R O A}$ is the deviation from the corresponding industry-year median of ROA (the ratio of net incomes to beginning total assets).

$\boldsymbol{a} \mathbf{L E V}$ is the deviation from the corresponding industry-year median of LEV (the ratio of total debts to total assets).

$\boldsymbol{a} \mathbf{C F O}$ is the deviation from the corresponding industry-year median of CFO (the ratio of operating cash flows to sales).

$a$ BLOAT is the deviation from the corresponding industry-year median of BLOAT, where BLOAT is shareholder's equity plus total debts minus cash and short-term investment scaled by sales.

M_SHARE is the percentage of a firm's sales to the total sales of its industry.

HERFINDAHL is the sum of squared market share of all firms in an industry, where the market share of a firm is its sales scaled by the total sales of its industry.

POF $=\frac{1}{\left(1+e^{-z}\right)}$, where $-Z=-7.1786+12.3826 x_{1}-20.9691 x_{2}-3.0174 x_{3}$, in which: $x_{1}$ is total liabilities divided by total assets; $x_{2}$ is earnings before interest and taxes divided by total liabilities; $x_{3}$ is cash flows from operations divided by total liabilities.

LOSS_FIRM is a dummy variable, which is one if a firm's net income is negative, and zero otherwise.

LOSS_IND is a dummy variable, which is one if the average net income of all firms in an industry is negative, and zero otherwise.

BIG4 is a dummy variable, which is one if a firm is audited by a Big 4 auditor, and zero otherwise.

SG_CYCLE is 1 (2 or 3) if a firm belongs to the top (middle or bottom, respectively) tercile sorted by sales growth within each industry-year, where sales growth is defined as the arithmetic growth of net sales compared to last year.

CAPEX_CYCLE is 1 (2 or 3 ) if a firm belongs to the top (middle or bottom, respectively) tercile sorted by capital expenditures within each industry-year.

DIV_CYCLE is 1 ( 2 or 3 ) if a firm belongs to the bottom (middle or top, respectively) tercile sorted by cash dividends within each industry-year.

AGE_CYCLE is 1 (2 or 3) if a firm belongs to the bottom (middle or top, respectively) tercile sorted by firm age within each industry-year.

CYCLE is the sum of SG_CYCLE, CAPEX_CYCLE, DIV_CYCLE and AGE_CYCLE.

EXPAND is a dummy variable, which takes the value of one if CYCLE is 7 or smaller, zero otherwise. 
$\mathbf{R I V}$ is the residual income valuation model's intrinsic values, measured as $R I V_{i, t}=B_{i, t}+\frac{\left(F R O E_{i, t}-r_{i, t}^{e}\right)}{\left(1+r_{i, t}^{e}\right)} \times$ $B_{i, t}+\frac{\left(F R O E_{i, t}-r_{i, t}^{e}\right)}{\left(1+r_{i, t}^{e}\right) \times r_{i, t}^{e}} \times B_{i, t}$, where B and FROE are the book value of equity and future return on equity derived from Bloomberg's BEst consensus using the sequential process as outlined in Frankel and Lee (1998); $\mathrm{r}^{\mathrm{e}}$ is the cost of equity, estimated using the Fama and French (1993) three-factor model augmented by the momentum factor (Carhart, 1997).

RVE is the price-to-value ratio, estimated as the market value divided by RIV.

RSOV is a dummy variable, which is one if a firm's RVE is higher than or equal to the corresponding industry-year $95^{\text {th }}$ percentile.

RROV is a dummy variable, which is one if a firm's RVE is higher than or equal to the corresponding industry-year $80^{\text {th }}$ percentile but smaller than the $95^{\text {th }}$ percentile.

LSOV is a dummy variable, which is one if a firm's FVE is higher than or equal to the corresponding industry-year $90^{\text {th }}$ percentile.

LROV is a dummy variable, which is one if a firm's FVE is higher than or equal to the corresponding industry-year $67^{\text {th }}$ percentile but smaller than the $90^{\text {th }}$ percentile. 
Table 1. Descriptive Statistics

\begin{tabular}{lrrrrr}
\hline Variables & Mean & $\begin{array}{r}\text { 25th } \\
\text { percentile }\end{array}$ & Median & $\begin{array}{r}\text { 75th } \\
\text { percentile }\end{array}$ & $\begin{array}{r}\text { Standard } \\
\text { deviation }\end{array}$ \\
\hline Ab_AC $_{\mathrm{t}}$ & 0.0035 & -0.0459 & 0.0076 & 0.0605 & 0.1207 \\
Ab_DEX $_{\mathrm{t}}$ & 0.0321 & -0.0719 & 0.0413 & 0.1662 & 0.2629 \\
FVE $_{\mathrm{t}-1}$ & 1.2001 & 0.6396 & 0.9736 & 1.4447 & 0.8976 \\
$a \mathrm{SIZE} t \mathrm{t}-1$ & 0.1248 & -1.0927 & 0.0000 & 1.1982 & 1.7861 \\
VB $_{\mathrm{t}-1}$ & 2.5170 & 1.2880 & 1.9646 & 2.9535 & 2.1159 \\
$a$ ROA $_{\mathrm{t}}$ & -0.0367 & -0.0631 & 0.0000 & 0.0487 & 0.1910 \\
$a$ LEV $_{\mathrm{t}-1}$ & 0.0258 & -0.0640 & 0.0000 & 0.1027 & 0.1361 \\
$a$ CFO $_{\mathrm{t}}$ & -0.4565 & -0.0537 & 0.0000 & 0.0568 & 2.7076 \\
$a \mathrm{BLOAT}_{\mathrm{t}-1}$ & 1.0731 & -0.1771 & 0.0000 & 0.3209 & 5.9533 \\
HERFINDAHL $_{\mathrm{t}}$ & 0.2705 & 0.1318 & 0.2232 & 0.3684 & 0.1941 \\
M_SHARE $_{\mathrm{t}}$ & 0.0611 & 0.0027 & 0.0115 & 0.0495 & 0.1278 \\
POF $_{\mathrm{t}}$ & 0.3561 & 0.1402 & 0.2361 & 0.8993 & 0.4181 \\
LOSS_FIRM $_{\mathrm{t}}$ & 0.3232 & 0.0000 & 0.0000 & 1.0000 & 0.4677 \\
LOSS_IND $_{\mathrm{t}}$ & 0.1648 & 0.0000 & 0.0000 & 0.0000 & 0.3710 \\
BIG4 $_{\mathrm{t}}$ & 0.5482 & 0.0000 & 1.0000 & 1.0000 & 0.4977 \\
\hline
\end{tabular}

Notes: The table reports basic descriptive statistics of selected variables for the final sample $(n=11,851$ observations). Definitions of the variables are provided in the Appendix. 
Table 2. Correlations

\begin{tabular}{|c|c|c|c|c|c|c|c|c|c|c|c|c|c|c|c|}
\hline Variable & & (1) & (2) & (3) & (4) & (5) & (6) & (7) & (8) & (9) & (10) & (11) & (12) & (13) & (14) \\
\hline$A b \_A C_{t}$ & (1) & & & & & & & & & & & & & & \\
\hline$A b \_D E X_{t}$ & (2) & 0.045 & & & & & & & & & & & & & \\
\hline $\mathrm{FVE}_{\mathrm{t}-1}$ & (3) & -0.009 & -0.121 & & & & & & & & & & & & \\
\hline $\mathrm{VB}_{\mathrm{tm1}}$ & (5) & 0.055 & -0.072 & 0.173 & 0.036 & & & & & & & & & & \\
\hline$a \mathrm{ROA}_{\mathrm{t}}$ & (6) & 0.381 & 0.204 & -0.005 & 0.235 & -0.039 & & & & & & & & & \\
\hline$a \mathrm{LEV}_{\mathrm{t}-1}$ & (7) & -0.004 & 0.092 & -0.008 & 0.107 & 0.067 & 0.038 & & & & & & & & \\
\hline HERFINDAHL & (10) & -0.008 & -0.012 & 0.009 & 0.045 & 0.012 & -0.030 & -0.007 & -0.051 & 0.034 & & & & & \\
\hline $\mathrm{M}_{-} \mathrm{SHARE}_{\mathrm{t}}$ & (11) & -0.010 & 0.048 & 0.060 & 0.545 & 0.025 & 0.147 & 0.137 & 0.089 & -0.082 & 0.183 & & & & \\
\hline $\mathrm{POF}_{\mathrm{t}}$ & (12) & 0.070 & -0.084 & -0.078 & 0.247 & -0.082 & 0.454 & -0.159 & 0.269 & -0.194 & -0.076 & 0.090 & & & \\
\hline LOSS_FIRM $_{\mathrm{t}}$ & (13) & -0.247 & -0.097 & 0.074 & -0.235 & 0.005 & -0.631 & 0.006 & -0.251 & 0.187 & 0.088 & -0.142 & -0.509 & & \\
\hline LOSS_IND & (14) & -0.007 & 0.007 & 0.023 & -0.006 & 0.097 & -0.029 & 0.025 & -0.062 & 0.053 & 0.027 & 0.051 & -0.155 & 0.218 & \\
\hline
\end{tabular}

Notes: The table reports Pearson correlation coefficients between the main variables. The coefficients reported in bold are significant at the $5 \%$ level. Definitions of the variables are provided in the Appendix. 
Table 3. Comparison of Proxies for Earnings Management, Market Mispricing and Fundamentals Between Substantially Overvalued Firms, Relatively Overvalued Firms, and the Rest of the Sample

\begin{tabular}{|c|c|c|c|c|c|c|c|c|c|c|c|c|c|c|}
\hline \multirow[b]{3}{*}{ Group } & \multicolumn{5}{|c|}{ All sample $(n=11,851)$} & \multicolumn{4}{|c|}{ Within the top FVE quintile $(n=2,335)$} & \multirow[t]{2}{*}{$\begin{array}{l}\text { 80th-95th } \\
\text { (ROV) }\end{array}$} & \multirow[t]{2}{*}{$\begin{array}{l}<80 \text { th (Rest } \\
\text { of sample) }\end{array}$} & \multirow[t]{2}{*}{$\begin{array}{c}\text { ROV minus } \\
\text { Rest }\end{array}$} & \multirow[t]{2}{*}{$\begin{array}{c}\text { SOV minus } \\
\text { Rest }\end{array}$} & \multirow[t]{2}{*}{$\begin{array}{l}\text { SOV minus } \\
\text { ROV }\end{array}$} \\
\hline & $<20$ th & 20th-40th & $\begin{array}{l}\text { 40th- } \\
\text { 60th }\end{array}$ & $\begin{array}{l}\text { 60th- } \\
\text { 80th }\end{array}$ & $>=80$ th & 80th-85th & 85th-90th & 90th-95th & $\begin{array}{l}>=95 \text { th } \\
\text { (SOV) }\end{array}$ & & & & & \\
\hline & 1 & 2 & 3 & 4 & 5 & 6 & 7 & 8 & 8 & & & & & \\
\hline $\mathrm{n}$ & 2,396 & 2,368 & 2,385 & 2,367 & 2,335 & 532 & 631 & 538 & 634 & 1,701 & 9,516 & & & \\
\hline$A b \_A C_{t}$ & -0.0091 & 0.0034 & 0.0031 & 0.0059 & 0.0145 & 0.0049 & 0.0033 & 0.0096 & 0.0380 & 0.0058 & 0.0008 & 0.005 & $0.0372 * * *$ & $0.0322 * * *$ \\
\hline$A b \_D E X_{t}$ & 0.0202 & 0.0581 & 0.0389 & 0.0240 & 0.0195 & 0.0142 & -0.0100 & -0.0423 & 0.1057 & -0.0127 & 0.0353 & $-0.0479 * * *$ & $0.0704 * * *$ & $0.1184^{* * *}$ \\
\hline $\mathrm{FVE}_{\mathrm{t}-1}$ & 0.9222 & 0.7115 & 0.9912 & 1.3738 & 2.4452 & 1.7907 & 2.0131 & 2.5874 & 3.3037 & 2.1252 & 0.9994 & $1.1258^{* * *}$ & $2.3043^{* * *}$ & $1.1785^{* * *}$ \\
\hline $\mathrm{FIV}_{\mathrm{t}-1}$ & 279,710 & 635,178 & 555,805 & 705,332 & 660,265 & 573,594 & 717,320 & 400,043 & 897,026 & 572,019 & 543,233 & 28,786 & 353,793 & 325,007 \\
\hline $\mathrm{MVE}_{\mathrm{t}-1}$ & 283,334 & 353,821 & 565,864 & 936,419 & $1,310,506$ & $1,049,775$ & $1,345,964$ & 914,444 & $1,830,089$ & $1,116,845$ & 534,132 & $582,713^{* * *}$ & $1,295,957^{* * *}$ & 713,244 \\
\hline SALE $_{\mathrm{t}}$ & 312,739 & 433,543 & 582,992 & 791,295 & 792,191 & 680,460 & 938,696 & 553,516 & 942,669 & 736,104 & 529,570 & $206,535^{* *}$ & $413,100 * *$ & 206,565 \\
\hline $\mathrm{TA}_{\mathrm{t}-1}$ & 266,516 & 555,836 & 666,762 & 889,705 & 888,973 & 700,101 & 960,901 & 537,776 & $1,273,889$ & 745,506 & 593,837 & 151,669 & $680,052 *$ & 528,383 \\
\hline $\mathrm{VB}_{\mathrm{t}-1}$ & 2.6221 & 2.4052 & 2.4111 & 2.5250 & 2.6227 & 2.5485 & 2.7950 & 2.7081 & 2.4410 & 2.6904 & 2.4911 & $0.1993 * * *$ & -0.0501 & $0.2494 * *$ \\
\hline $\mathrm{ROA}_{\mathrm{t}}$ & -0.0719 & -0.0071 & -0.0108 & -0.0027 & 0.0041 & 0.0165 & 0.0047 & -0.0365 & 0.0274 & -0.0047 & -0.0232 & $0.0186 * *$ & $0.0507 * * *$ & $0.0321 * * *$ \\
\hline $\mathrm{LEV}_{\mathrm{t}-1}$ & 0.1499 & 0.1535 & 0.1533 & 0.1513 & 0.1622 & 0.1658 & 0.1595 & 0.1474 & 0.1743 & 0.1577 & 0.1520 & 0.0057 & $0.0223 * * *$ & $0.0166^{* *}$ \\
\hline
\end{tabular}

Notes: Within each industry-year, firms are sorted based on FVE. Group $1(2,3,4,5)$ comprises firms in the bottom $\left(2^{\text {nd }}, 3^{\text {rd }}, 4^{\text {th }}, 5^{\text {th }}\right.$, respectively) quintile. Group $6(7,8)$, defined as ROV firms, comprises firms that have an FVE higher than or equal to the corresponding industry-year $80^{\text {th }}$ percentile but smaller than the $85^{\text {th }}$ percentile (higher than or equal to the corresponding industry-year $85^{\text {th }}$ percentile but smaller than the $90^{\text {th }}$ percentile, and higher than or equal to the corresponding industry-year $90^{\text {th }}$ percentile but smaller than the $95^{\text {th }}$ percentile, respectively). Group 9 , defined as SOV firms, comprises firms that have an FVE higher than or equal to the corresponding industry-year $95^{\text {th }}$ percentile. The rest of the sample refers to firms that have an FVE smaller than the corresponding industry-year $80^{\text {th }}$ percentile. The table reports the means of the proxies for earnings management, market mispricing and selected fundamentals for each of the groups. The last three columns report the t-tests comparing the mean between SOV, ROV firms and the rest of sample. ${ }^{*},{ }^{* *},{ }^{* * *}$ denote two-tailed significance at the $10 \%, 5 \%, 1 \%$ levels, respectively. Definitions of the variables are provided in the Appendix. 
Table 4. Proxies for Earnings Management Regressed on Indicators of Substantially Overvalued and Relatively Overvalued Firms and Control Variables

\begin{tabular}{|c|c|c|c|c|}
\hline \multirow[b]{2}{*}{ Variables } & \multicolumn{2}{|c|}{ Ab_DEX } & \multicolumn{2}{|c|}{$A b \_A C$} \\
\hline & Coefficient & t-statistic & Coefficient & t-statistic \\
\hline $\mathrm{FSOV}_{\mathrm{t}-1}$ & 0.0575 & $5.46 * * *$ & 0.0407 & $3.82 * * *$ \\
\hline FROV $_{\mathrm{t}-1}$ & -0.0503 & $-7.36 * * *$ & -0.0103 & -1.13 \\
\hline INTERCEPT & 0.0524 & $6.04 * * *$ & 0.0458 & $5.1 * * *$ \\
\hline$a S I Z E_{t-1}$ & -0.0011 & -0.62 & -0.0059 & $-9.4 * * *$ \\
\hline$V B_{t-1}$ & -0.0081 & $-7.18 * * *$ & 0.001 & 0.72 \\
\hline$a \mathrm{ROA}_{\mathrm{t}}$ & 0.3085 & $18.72^{* * *}$ & 0.37 & $7.02 * * *$ \\
\hline$a \mathrm{LEV}_{\mathrm{t}-1}$ & 0.1782 & $10.01 * * *$ & 0.0292 & 0.92 \\
\hline$a \mathrm{CFO}_{\mathrm{t}}$ & & & -0.007 & $-15.62 * * *$ \\
\hline$a \mathrm{BLOAT}_{\mathrm{t}-1}$ & 0.0021 & $5.17 * * *$ & -0.0024 & $-1.73^{*}$ \\
\hline HERFINDAHL $_{t}$ & 0.0232 & $1.86^{*}$ & & \\
\hline M_SHARE $_{t}$ & 0.0451 & $2.01 * *$ & & \\
\hline $\mathrm{POF}_{\mathrm{t}}$ & -0.0286 & $-7.01 * * *$ & 0.0164 & $2.35^{* *}$ \\
\hline LOSS_FIRMt & 0.0262 & $3.71 * * *$ & -0.0107 & $-2.06 * *$ \\
\hline LOSS_IND & 0.0049 & 0.74 & -0.0018 & -0.58 \\
\hline$B I G 4_{t}$ & -0.0141 & -0.85 & -0.007 & $-2.22 * *$ \\
\hline PABDEX $_{t}$ & & & -0.2644 & -1.55 \\
\hline UABDEX $_{\mathrm{t}}$ & & & -0.0127 & $-3.24 * * *$ \\
\hline
\end{tabular}

Notes: The table reports the results of estimating the following regressions, jointly using a recursive equation system using the full sample $(\mathrm{n}=11,851)$ :

$$
\begin{aligned}
& A b_{-} D E X_{i, t}=\alpha+\beta_{1}\left(F S O V_{i, t-1}\right)+\beta_{2}\left(F R O V_{i, t-1}\right)+\beta_{3}\left(a S I Z E_{i, t-1}\right)+\beta_{4}\left(V B_{i, t-1}\right)+\beta_{5}\left(a R O A_{i, t}\right)+ \\
& \beta_{6}\left(\operatorname{aLEV}_{i, t-1}\right)+\beta_{7}\left(\operatorname{aBLOAT}_{i, t-1}\right)+\beta_{8}\left(\operatorname{HERFINDAHL}_{i, t}\right)+\beta_{9}\left(M_{-} S H A R E_{i, t}\right)+\beta_{10}\left(\text { POF }_{i, t}\right)+ \\
& \beta_{11}\left(\text { LOSS_FIRM }_{i, t}\right)+\beta_{12}\left(\text { LOSS_IND }_{i, t}\right)+\beta_{13}\left(\text { BIG4 }_{i, t}\right)+\varepsilon_{i, t} \\
& A b_{-} A C_{i, t}=\alpha+\beta_{1}\left(F S O V_{i, t-1}\right)+\beta_{2}\left(F R O V_{i, t-1}\right)+\beta_{3}\left(\operatorname{aSIZE}_{i, t-1}\right)+\beta_{4}\left(V B_{i, t-1}\right)+\beta_{5}\left(a R O A_{i, t}\right)+ \\
& \beta_{6}\left(a L E V_{i, t-1}\right)+\beta_{7}\left(a C F O_{i, t}\right)+\beta_{8}\left(a B L O A T_{i, t-1}\right)+\beta_{9}\left(\text { POF }_{i, t}\right)+\beta_{10}\left(\operatorname{LOSS}_{-} F I R M_{i, t}\right)+ \\
& \beta_{11}\left(\text { LOSS }_{-} I N D_{i, t}\right)+\beta_{12}\left(B_{1 G 4_{i, t}}\right)+\beta_{13}\left(\text { PABDEX }_{i, t}\right)+\beta_{12}\left(\text { UABDEX }_{i, t}\right)+\varepsilon_{i, t}
\end{aligned}
$$

T-statistics are calculated using robust standard errors clustered by both firm and year (Petersen, 2009). *, **, ${ }^{* * *}$ denote two-tailed significance at the $10 \%, 5 \%, 1 \%$ levels, respectively. Definitions of the variables are provided in the Appendix. 
Table 5. Proxies for Earnings Management Regressed on Indicators of Substantially Overvalued and Relatively Overvalued Firms, Indicator of Expanding Firms and Control Variables

\begin{tabular}{|c|c|c|c|c|}
\hline \multirow[b]{2}{*}{ Variables } & \multicolumn{2}{|c|}{ Ab_DEX } & \multicolumn{2}{|c|}{$A b \_A C$} \\
\hline & Coefficient & t-statistic & Coefficient & t-statistic \\
\hline $\mathrm{FSOV}_{\mathrm{t}-1}$ & 0.0628 & $5.25 * * *$ & 0.0402 & $3.32 * * *$ \\
\hline $\mathrm{FROV}_{\mathrm{t}-1}$ & -0.0116 & -1.45 & -0.0083 & $-2.05 * *$ \\
\hline EXPAND $_{t}$ & -0.0325 & $-5.24 * * *$ & 0.0139 & $2.17^{* *}$ \\
\hline FSOV $_{\mathrm{t}-1} *$ EXPAND $_{\mathrm{t}}$ & -0.0194 & -0.77 & 0.0175 & 1.58 \\
\hline $\mathrm{FROV}_{\mathrm{t}-1} * \operatorname{EXPAND}_{\mathrm{t}}$ & -0.1449 & $-9.6 * * *$ & -0.0218 & -0.82 \\
\hline INTERCEPT & 0.0421 & $4.72 * * *$ & 0.0446 & $5.78 * * *$ \\
\hline$a \mathrm{SIZE}_{\mathrm{t}-1}$ & -0.0009 & -0.53 & -0.0053 & $-8.17 * * *$ \\
\hline$V B_{t-1}$ & -0.0076 & $-6.79 * * *$ & 0.0008 & 0.55 \\
\hline$a \mathrm{ROA}_{\mathrm{t}}$ & 0.3079 & $18.65^{* * *}$ & 0.3918 & $7.19 * * *$ \\
\hline$a \mathrm{LEV}_{\mathrm{t}-1}$ & 0.1695 & $9.54 * * *$ & 0.038 & 1.21 \\
\hline$a \mathrm{CFO}_{\mathrm{t}}$ & & & -0.0069 & $-15.33 * * *$ \\
\hline$a \mathrm{BLOAT}_{\mathrm{t}-1}$ & 0.0021 & $5.27 * * *$ & -0.0002 & -0.57 \\
\hline HERFINDAHL $_{t}$ & 0.0211 & $1.7^{*}$ & & \\
\hline M_SHARE $_{t}$ & 0.0456 & $2.03 * *$ & & \\
\hline $\mathrm{POF}_{\mathrm{t}}$ & -0.027 & $-6.38 * * *$ & 0.0172 & $2.46^{* *}$ \\
\hline LOSS_FIRMt & 0.0254 & $3.62 * * *$ & -0.0097 & $-1.86^{*}$ \\
\hline LOSS_IND & 0.0068 & 1.03 & -0.0002 & -0.04 \\
\hline$B \mid G 4_{t}$ & -0.0145 & -0.94 & -0.0081 & $-2.48 * *$ \\
\hline PABDEX $_{t}$ & & & -0.3257 & $-1.84^{*}$ \\
\hline UABDEX $_{t}$ & & & -0.0117 & $-2.97 * * *$ \\
\hline
\end{tabular}

Notes: The table reports the results of estimating the following regressions jointly using a recursive equation system using the full sample $(\mathrm{n}=11,851)$ :

$$
\begin{aligned}
& A b_{-} D E X_{i, t}=\alpha+\beta_{1}\left(F_{S O V}{ }_{i, t-1}\right)+\beta_{2}\left(F R O V_{i, t-1}\right)+\beta_{3}\left(\operatorname{EXPAND}_{i, t}\right)+\beta_{4}\left(\text { FSOV }_{i, t-1} \times \text { EXPAND }_{i, t}\right)+ \\
& \beta_{5}\left(\text { FROV }_{i, t-1} \times \operatorname{EXPAND}_{i, t}\right)+\beta_{6}\left(\operatorname{aSIZE}_{i, t-1}\right)+\beta_{7}\left(V B_{i, t-1}\right)+\beta_{8}\left(a R O A_{i, t}\right)+ \\
& \beta_{9}\left(\operatorname{aLEV}_{i, t-1}\right)+\beta_{10}\left(\operatorname{aBLOAT}_{i, t-1}\right)+\beta_{11}\left(\operatorname{HERFINDAHL}_{i, t}\right)+\beta_{12}\left(M_{-} S H A R E_{i, t}\right)+ \\
& \beta_{13}\left(\text { POF }_{i, t}\right)+\beta_{14}\left(\text { LOSS_FIRM }_{i, t}\right)+\beta_{15}\left(\text { LOSS_IND }_{i, t}\right)+\beta_{16}\left(B I G 4_{i, t}\right)+\varepsilon_{i, t} \\
& A b_{-} A C_{i, t}=\alpha+\beta_{1}\left(F \text { SOV }_{i, t-1}\right)+\beta_{2}\left(F_{R O V_{i, t-1}}\right)+\beta_{3}\left(\operatorname{EXPAND}_{i, t}\right)+\beta_{4}\left(\text { FSOV }_{i, t-1} \times \operatorname{EXPAND}_{i, t}\right)+
\end{aligned}
$$

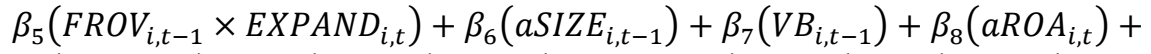

$$
\begin{aligned}
& \beta_{9}\left(a L E V_{i, t-1}\right)+\beta_{10}\left(\text { aCFO }_{i, t}\right)+\beta_{11}\left(\text { aBLOAT }_{i, t-1}\right)+\beta_{12}\left(\text { POF }_{i, t}\right)+\beta_{13}\left(\text { LOSS_FIRM }_{i, t}\right)+ \\
& \beta_{14}\left(\text { LOSS IND }_{i, t}\right)+\beta_{15}\left(\text { BIG4 }_{i, t}\right)+\beta_{16}\left(\text { PABDEX }_{i, t}\right)+\beta_{17}\left(\text { UABDEX X }_{i, t}\right)+\varepsilon_{i, t}
\end{aligned}
$$

T-statistics are calculated using robust standard errors clustered by both firm and year (Petersen, 2009). ${ }^{*},{ }^{* *},{ }^{* * *}$ denote two-tailed significance at the $10 \%, 5 \%, 1 \%$ levels, respectively. Definitions of the variables are provided in the Appendix. 
Table 6. Proxies for Earnings Management Regressed on Indicators of Substantially Overvalued and Relatively Overvalued Firms, Indicator of Expanding Firms and Control Variables Where Substantially Overvalued and Relatively Overvalued Firms are Identified using the Residual Income Valuation Model

\begin{tabular}{|c|c|c|c|c|c|c|c|c|}
\hline \multirow[b]{2}{*}{ Variables } & \multicolumn{4}{|c|}{ Ab_DEX } & \multicolumn{4}{|c|}{ Ab_AC } \\
\hline & Coefficient & t-statistic & Coefficient & t-statistic & Coefficient & t-statistic & Coefficient & t-statistic \\
\hline (1) & $(2)$ & (3) & (4) & (5) & $(6)$ & (7) & (8) & (9) \\
\hline $\mathrm{RSOV}_{\mathrm{t}-1}$ & 0.0594 & $2.03^{* *}$ & 0.0554 & $1.84^{*}$ & 0.028 & $1.72 *$ & -0.0026 & -0.29 \\
\hline $\mathrm{RROV}_{\mathrm{t}-1}$ & -0.0305 & $-1.72 *$ & -0.0288 & -1.57 & -0.0051 & -0.51 & -0.0181 & $-3.46 * * *$ \\
\hline EXPAND $_{t}$ & & & -0.0479 & $-2.6 * * *$ & & & 0.0087 & 1.16 \\
\hline $\mathrm{RSOV}_{\mathrm{t}-1}{ }^{*}$ EXPAND $_{\mathrm{t}}$ & & & 0.1258 & 1.04 & & & 0.0301 & 0.71 \\
\hline RROV $_{\mathrm{t}-1}{ }^{*}$ EXPAND $_{\mathrm{t}}$ & & & -0.0242 & $-2.42^{* *}$ & & & 0.0125 & 0.69 \\
\hline INTERCEPT & 0.1147 & $4.06 * * *$ & 0.1285 & $4.49 * * *$ & 0.0879 & $3 * * *$ & 0.0576 & $3.62 * * *$ \\
\hline$a \mathrm{SIZE}_{\mathrm{t}-1}$ & 0.0079 & $1.85^{*}$ & 0.0065 & 1.51 & -0.0018 & -0.94 & -0.0017 & -1.4 \\
\hline $\mathrm{VB}_{\mathrm{t}-1}$ & -0.002 & -0.54 & -0.0019 & -0.51 & -0.0057 & $-4.45 * * *$ & -0.0049 & $-4.14 * * *$ \\
\hline$a \mathrm{ROA}_{\mathrm{t}}$ & -0.1741 & $-2.55^{* *}$ & -0.1957 & $-2.84 * * *$ & 0.3137 & $6.67 * * *$ & 0.3756 & $12.89 * * *$ \\
\hline$a \mathrm{LEV}_{\mathrm{t}-1}$ & 0.2878 & $6.39 * * *$ & 0.2808 & $6.24 * * *$ & 0.094 & 1.28 & 0.013 & 0.4 \\
\hline$a \mathrm{CFO}_{\mathrm{t}}$ & & & & & -0.0277 & $-8.92 * * *$ & -0.0275 & $-8.89 * * *$ \\
\hline$a \mathrm{BLOAT}_{\mathrm{t}-1}$ & 0.0159 & $2.36 * *$ & 0.0175 & $2.58 * * *$ & -0.0118 & $-2.56^{* *}$ & -0.0065 & $-2.32 * *$ \\
\hline HERFINDAHL $L_{t}$ & 0.005 & 0.18 & 0.0021 & 0.07 & & & & \\
\hline $\mathrm{M}_{-} \mathrm{SHARE}_{\mathrm{t}}$ & -0.0523 & -1.25 & -0.0548 & -1.31 & & & & \\
\hline $\mathrm{POF}_{\mathrm{t}}$ & -0.0663 & $-2.59 * * *$ & -0.0709 & $-2.76 * * *$ & 0.0508 & $2.8 * * *$ & 0.034 & $3.11 * * *$ \\
\hline LOSS_FIRM $_{t}$ & -0.0599 & $-2.77 * * *$ & -0.0556 & $-2.56 * *$ & -0.0551 & $-3.39 * * *$ & -0.0374 & $-4.15^{* * *}$ \\
\hline LOSS_IND & -0.0195 & -1 & -0.02 & -1.02 & -0.0052 & -0.63 & -0.0002 & -0.03 \\
\hline $\mathrm{BIG}_{\mathrm{t}}$ & -0.0202 & -1.48 & -0.0202 & -1.48 & -0.0199 & $-3.02 * * *$ & -0.0149 & $-3.04 * * *$ \\
\hline PABDEX $_{t}$ & & & & & -0.3425 & -1.36 & -0.0556 & -0.51 \\
\hline UABDEX & & & & & -0.0396 & $-5.08 * * *$ & -0.0395 & $-5.06 * * *$ \\
\hline
\end{tabular}

Notes: Columns (2), (3) and (6), (7) report the results of estimating the following regressions jointly using a recursive equation system using the sub-sample, which keeps only firms that have enough data to estimate RIV $(n=1,684)$ : 
$A b_{-} D E X_{i, t}=\alpha+\beta_{1}\left(\operatorname{RSOV}_{i, t-1}\right)+\beta_{2}\left(\operatorname{RROV}_{i, t-1}\right)+\beta_{3}\left(\operatorname{aSIZE}_{i, t-1}\right)+\beta_{4}\left(V_{i, t-1}\right)+\beta_{5}\left(a R O A_{i, t}\right)+\beta_{6}\left(a L E V_{i, t-1}\right)+\beta_{7}\left(a B L O A T_{i, t-1}\right)+\beta_{8}\left(\right.$ HERFINDAHL $\left._{i, t}\right)+$ $\beta_{9}\left(M_{-} S H A R E_{i, t}\right)+\beta_{10}\left(P O F_{i, t}\right)+\beta_{11}\left(\right.$ LOSS_FIRM $\left._{i, t}\right)+\beta_{12}\left(\right.$ LOSS IND $\left._{i, t}\right)+\beta_{13}\left(B I G 4_{i, t}\right)+\varepsilon_{i, t}$

$A b_{-} A C_{i, t}=\alpha+\beta_{1}\left(\operatorname{RSOV}_{i, t-1}\right)+\beta_{2}\left(\operatorname{RROV}_{i, t-1}\right)+\beta_{3}\left(\operatorname{aSIZE}_{i, t-1}\right)+\beta_{4}\left(\operatorname{VB}_{i, t-1}\right)+\beta_{5}\left(\operatorname{aROA}_{i, t}\right)+\beta_{6}\left(\operatorname{aLEV}_{i, t-1}\right)+\beta_{7}\left(\operatorname{aCFO}_{i, t}\right)+\beta_{8}\left(\operatorname{aBLOAT}_{i, t-1}\right)+$ $\beta_{9}\left(\right.$ POF $\left._{i, t}\right)+\beta_{10}\left(\right.$ LOSS_FIRM $\left._{i, t}\right)+\beta_{11}\left(\right.$ LOSS IIND $\left._{i, t}\right)+\beta_{12}\left(\right.$ BIG4 $\left._{i, t}\right)+\beta_{13}\left(\right.$ PABDEX $\left._{i, t}\right)+\beta_{12}\left(\right.$ UABDEX $\left._{i, t}\right)+\varepsilon_{i, t}$

Columns (4), (5) and (8), (9) report the results of estimating the following regressions, jointly using a recursive equation system using the sub-sample, which keeps only firms that have enough data to estimate RIV $(n=1,684)$ :

$A b_{-} D E X_{i, t}=\alpha+\beta_{1}\left(\operatorname{RSOV}_{i, t-1}\right)+\beta_{2}\left(\operatorname{RROV}_{i, t-1}\right)+\beta_{3}\left(\operatorname{EXPAND}_{i, t}\right)+\beta_{4}\left(\operatorname{RSOV}_{i, t-1} \times \operatorname{EXPAND}_{i, t}\right)+\beta_{5}\left(\operatorname{RROV}_{i, t-1} \times \operatorname{EXPAND}_{i, t}\right)+\beta_{6}\left(\operatorname{aSIZE}_{i, t-1}\right)+$ $\beta_{7}\left(V B_{i, t-1}\right)+\beta_{8}\left(a R O A_{i, t}\right)+\beta_{9}\left(a L E V_{i, t-1}\right)+\beta_{10}\left(a B L O A T_{i, t-1}\right)+\beta_{11}\left(\operatorname{HERFINDAHL}_{i, t}\right)+\beta_{12}\left(M_{-} \operatorname{SHARE}_{i, t}\right)+\beta_{13}\left(\right.$ POF Fi,t $\left._{i, t}\right)+\beta_{14}\left(\right.$ LOSS_FIRM $\left._{i, t}\right)+$ $\beta_{15}\left(\right.$ LOSS IND $\left._{i, t}\right)+\beta_{16}\left(B I G 4_{i, t}\right)+\varepsilon_{i, t}$

$A b_{-} A C_{i, t}=\alpha+\beta_{1}\left(\operatorname{RSOV}_{i, t-1}\right)+\beta_{2}\left(\operatorname{RROV}_{i, t-1}\right)+\beta_{3}\left(\operatorname{EXPAND}_{i, t}\right)+\beta_{4}\left(\operatorname{RSOV}_{i, t-1} \times \operatorname{EXPAND}_{i, t}\right)+\beta_{5}\left(\operatorname{RROV}_{i, t-1} \times \operatorname{EXPAND}_{i, t}\right)+\beta_{6}\left(\operatorname{aSIZE}_{i, t-1}\right)+$ $\beta_{7}\left(V_{i, t-1}\right)+\beta_{8}\left(a R O A_{i, t}\right)+\beta_{9}\left(\right.$ aLEV $\left._{i, t-1}\right)+\beta_{10}\left(a C F O_{i, t}\right)+\beta_{11}\left(a B L O A T_{i, t-1}\right)+\beta_{12}\left(P O F_{i, t}\right)+\beta_{13}\left(\right.$ LOSS_FIRM $\left._{i, t}\right)+\beta_{14}\left(\right.$ LOSS IND $\left._{i, t}\right)+$ $\beta_{15}\left(B I G 4_{i, t}\right)+\beta_{16}\left(\right.$ PABDEX $\left._{i, t}\right)+\beta_{17}\left(\right.$ UABDEX $\left._{i, t}\right)+\varepsilon_{i, t}$

T-statistics are calculated using robust standard errors clustered by both firm and year (Petersen, 2009). * **, *** denote two-tailed significance at the 10\%, $5 \%, 1 \%$ levels, respectively. Definitions of the variables are provided in the Appendix. 
Table 7. Proxies for Earnings Management Regressed on Indicators of Substantially Overvalued and Relatively Overvalued Firms, Indicator of Expanding Firms and Control Variables Where Substantially Overvalued and Relatively Overvalued Firms are Identified using Lower Benchmarks

\begin{tabular}{|c|c|c|c|c|c|c|c|c|}
\hline \multirow[b]{2}{*}{ Variable } & \multicolumn{4}{|c|}{ Ab_DEX } & \multicolumn{4}{|c|}{ Ab_AC } \\
\hline & Coefficient & t-statistic & Coefficient & t-statistic & Coefficient & t-statistic & Coefficient & t-statistic \\
\hline (1) & (2) & (3) & (4) & (5) & (6) & $(7)$ & (8) & (9) \\
\hline $\mathrm{LSOV}_{\mathrm{t}-1}$ & 0.0643 & $7.39 * * *$ & 0.0682 & $6.93 * * *$ & 0.0424 & $4.1 * * *$ & 0.0397 & $3.43 * * *$ \\
\hline $\mathrm{LROV}_{\mathrm{t}-1}$ & -0.0219 & $-3.76 * * *$ & 0.0109 & 1.62 & -0.0024 & -0.55 & 0.0014 & 0.44 \\
\hline EXPAND $_{t}$ & & & -0.0315 & $-4.78 * * *$ & & & 0.0106 & $1.8^{*}$ \\
\hline LSOV $_{\mathrm{t}-1} * \operatorname{EXPAND}_{\mathrm{t}}$ & & & -0.0106 & -0.51 & & & 0.0209 & $2.36 * *$ \\
\hline LROV $_{\mathrm{t}-1}{ }^{*}$ EXPAND $_{\mathrm{t}}$ & & & -0.1246 & $-9.7 * * *$ & & & -0.0188 & -0.89 \\
\hline INTERCEPT & 0.0436 & $4.95 * * *$ & 0.0351 & $3.88^{* * *}$ & 0.0420 & $5.82 * * *$ & 0.0400 & $6.29 * * *$ \\
\hline$a \mathrm{SIZE}_{\mathrm{t}-1}$ & -0.0028 & -1.61 & -0.0028 & -1.59 & -0.0065 & $-10.15^{* * *}$ & -0.0061 & $-9.28 * * *$ \\
\hline$V_{B_{t-1}}$ & -0.0081 & $-7.23 * * *$ & -0.0077 & $-6.88 * * *$ & 0.0011 & 0.83 & 0.0010 & 0.78 \\
\hline$a \mathrm{ROA}_{\mathrm{t}}$ & 0.3050 & $18.48 * * *$ & 0.3033 & $18.36 * * *$ & 0.3668 & $7.84 * * *$ & 0.3779 & $7.72 * * *$ \\
\hline$a \mathrm{LEV}_{\mathrm{t}-1}$ & 0.1791 & $10.05^{* * *}$ & 0.1740 & $9.8 * * *$ & 0.0290 & 1.01 & 0.0333 & 1.13 \\
\hline$a \mathrm{CFO}_{\mathrm{t}}$ & & & & & -0.0070 & $-15.57 * * *$ & -0.0069 & $-15.33 * * *$ \\
\hline$a \mathrm{BLOAT}_{\mathrm{t}-1}$ & 0.0021 & $5.08 * * *$ & 0.0021 & $5.16 * * *$ & -0.0004 & -1.2 & -0.0003 & -0.88 \\
\hline HERFINDAHL & 0.0215 & $1.72 *$ & 0.0204 & 1.63 & & & & \\
\hline M_SHAREt & 0.0563 & $2.5^{* *}$ & 0.0535 & $2.39 * *$ & & & & \\
\hline $\mathrm{POF}_{\mathrm{t}}$ & -0.0206 & $-2.95 * * *$ & -0.0199 & $-2.85 * * *$ & 0.0270 & $6.31 * * *$ & 0.0261 & $6.03 * * *$ \\
\hline LOSS_FIRM $_{t}$ & -0.0265 & $-3.76 * * *$ & -0.0257 & $-3.66 * * *$ & -0.0106 & $-2.19 * *$ & -0.0102 & $-2.08 * *$ \\
\hline LOSS_IND & -0.0062 & -0.94 & -0.0075 & -1.14 & -0.0011 & -0.37 & -0.0001 & 0.02 \\
\hline $\mathrm{BIG}_{\mathrm{t}}^{-}$ & -0.0138 & -1.18 & -0.0148 & -0.99 & -0.0068 & $-2.3 * *$ & -0.0075 & $-2.38 * *$ \\
\hline PABDEX $_{t}$ & & & & & -0.2601 & $-1.7^{*}$ & -0.2899 & $-1.8^{*}$ \\
\hline UABDEX $_{\mathrm{t}}$ & & & & & -0.0135 & $-3.44 * * *$ & -0.0127 & $-3.22 * * *$ \\
\hline
\end{tabular}

Notes: Columns (2), (3) and (6), (7) report the results of estimating the following regressions jointly using a recursive equation system using the full sample (n $=11,851$ ): 
$A b_{-} D E X_{i, t}=\alpha+\beta_{1}\left(L S O V_{i, t-1}\right)+\beta_{2}\left(L R O V_{i, t-1}\right)+\beta_{3}\left(a S I Z E_{i, t-1}\right)+\beta_{4}\left(V B_{i, t-1}\right)+\beta_{5}\left(a R O A_{i, t}\right)+\beta_{6}\left(a L E V_{i, t-1}\right)+\beta_{7}\left(a B L O A T_{i, t-1}\right)+\beta_{8}\left(H E R F I N D A H L_{i, t}\right)+$ $\beta_{9}\left(M_{-} S H A R E_{i, t}\right)+\beta_{10}\left(\right.$ POF $\left._{i, t}\right)+\beta_{11}\left(\right.$ LOSS_FIRM $\left._{i, t}\right)+\beta_{12}\left(\right.$ LOSS_IND $\left._{i, t}\right)+\beta_{13}\left(\right.$ BIG4 $\left._{i, t}\right)+\varepsilon_{i, t}$

$A b_{-} A C_{i, t}=\alpha+\beta_{1}\left(L S O V_{i, t-1}\right)+\beta_{2}\left(L R O V_{i, t-1}\right)+\beta_{3}\left(a S I Z E_{i, t-1}\right)+\beta_{4}\left(V B_{i, t-1}\right)+\beta_{5}\left(a R O A_{i, t}\right)+\beta_{6}\left(a L E V_{i, t-1}\right)+\beta_{7}\left(a C F O_{i, t}\right)+\beta_{8}\left(a B L O A T_{i, t-1}\right)+\beta_{9}\left(P O F_{i, t}\right)+$ $\beta_{10}\left(L_{\text {LOSS_FIRM }}\right)+\beta_{11}\left(\right.$ LOSS_IND $\left._{i, t}\right)+\beta_{12}\left(B_{\text {IG }} 4_{i, t}\right)+\beta_{13}\left(P A B D E X_{i, t}\right)+\beta_{12}\left(U A B D E X_{i, t}\right)+\varepsilon_{i, t}$

Columns (4), (5) and (8), (9) report the results of estimating the following regressions jointly using a recursive equation system using the full sample ( $=11,851$ ):

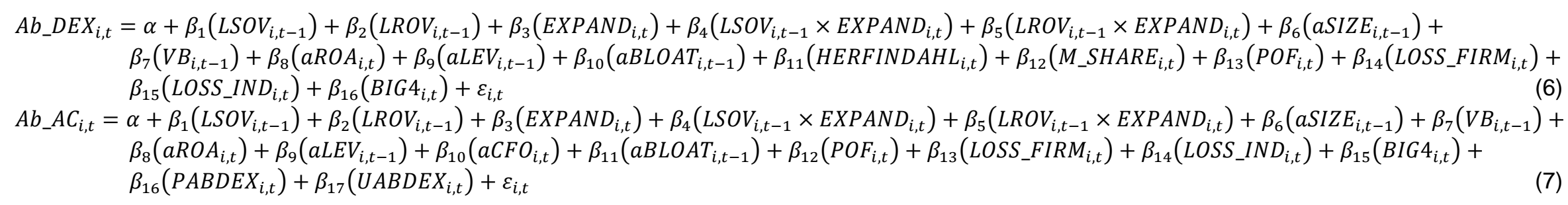

T-statistics are calculated using robust standard errors clustered by both firm and year (Petersen, 2009). *, ${ }^{* *},{ }^{* * *}$ denote two-tailed significance at the $10 \%$, $5 \%, 1 \%$ levels, respectively. Definitions of the variables are provided in the Appendix. 